\title{
Zombies at Large? \\ Corporate Debt Overhang and the Macroeconomy
}

\author{
Òscar Jordà \\ Federal Reserve Bank of San Francisco \\ Martin Kornejew \\ University of Bonn \\ Moritz Schularick \\ Federal Reserve Bank of New York
}

Alan M. Taylor

University of California, Davis

NBER and CEPR

December 2020

Working Paper 2020-36

https://www.frbsf.org/economic-research/publications/working-papers/2020/36/

\section{Suggested citation:}

Jordà, Òscar, Martin Kornejew, Moritz Schularick, Alan M. Taylor. 2020. “Zombies at Large? Corporate Debt Overhang and the Macroeconomy," Federal Reserve Bank of San Francisco Working Paper 2020-36. https://doi.org/10.24148/wp2020-36

The views in this paper are solely the responsibility of the authors and should not be interpreted as reflecting the views of the Federal Reserve Bank of San Francisco or the Board of Governors of the Federal Reserve System. 


\title{
Zombies at large? \\ Corporate debt overhang and the macroeconomy ${ }^{\star}$
}

\author{
Òscar Jordà $^{\dagger} \quad$ Martin Kornejew ${ }^{\ddagger}$ \\ Moritz Schularick§ Alan M. Taylor $\mathbb{I}$
}

December 2020

\begin{abstract}
With business leverage at record levels, the effects of corporate debt overhang on growth and investment have become a prominent concern. In this paper, we study the effects of corporate debt overhang based on long-run cross-country data covering the nearuniverse of modern business cycles. We show that business credit booms typically do not leave a lasting imprint on the macroeconomy. Quantile local projections indicate that business credit booms do not affect the economy's tail risks either. Yet in line with theory, we find that the economic costs of corporate debt booms rise when inefficient debt restructuring and liquidation impede the resolution of corporate financial distress and make it more likely that corporate zombies creep along.
\end{abstract}

Keywords: corporate debt, business cycles, local projections.

JEL classification codes: E44, G32, G33, N20.

${ }^{\star}$ We thank Karsten Müller for generously sharing his data on corporate bank credit, and Nina Boryachenko, Fernando Duarte, Anna Kovner, and John Williams for helpful comments and suggestions. Dean Parker provided research assistance. All errors are our own. Òscar Jordà, Moritz Schularick, and Alan M. Taylor gratefully acknowledge support from the Institute for New Economic Thinking. Martin Kornejew gratefully acknowledges support from RTG 2281 funded by the Deutsche Forschungsgemeinschaft (DFG). The views expressed herein are solely the responsibility of the authors and should not be interpreted as reflecting the views of the Federal Reserve Bank of San Francisco, the Federal Reserve Bank of New York, or the Board of Governors of the Federal Reserve System.

${ }^{\dagger}$ Federal Reserve Bank of San Francisco; and Department of Economics, University of California, Davis (oscar.jorda@sf.frb.org; ojorda@ucdavis.edu).

‡Department of Economics, University of Bonn (m.kornejew@uni-bonn.de).

\$Federal Reserve Bank of New York (moritz.schularick@ny.frb.org).

IIDepartment of Economics and Graduate School of Management, University of California, Davis; NBER; and CEPR (amtaylor@ucdavis.edu). 


\section{INTRODUCTION}

In a seminal departure from the classic Modigliani and Miller (1958) theorem on the irrelevance of the firm's capital structure, Myers (1977) showed that default risk undermines the incentives to invest for indebted firms. Some projects with positive net present value will not be realized as equity holders do not benefit in case of default. Debt overhang may depress any expenditure with delayed returns, such as hiring, training, advertising, or maintenance (Hennessey, 2004). If these concerns had wide application, then it would be reasonable to expect that, at the aggregate level, firm debt overhang could propagate, amplify, and prolong the effects of adverse business cycle shocks (Lamont, 1995; Occhino and Pescatori, 2015).

Over the last decade, since the Global Financial Crisis, concerns about the buildup in corporate debt around the world have grown louder. ${ }^{1}$ The debt level of the U.S. nonfinancial business sector increased by about 20 percentage points relative to GDP and now stands at a historical high of $130 \%$ of GDP (Board of Governors of the Federal Reserve System, 2020). On a global level, corporate debt has also risen strongly, especially in emerging markets (Abraham, Cortina, and Schmukler, 2020). Many fear that the COVID-19 pandemic has aggravated the situation as emergency lending facilities have pushed business debt ratios up even higher while earnings have fallen, potentially amplifying the risks from debt overhang. Consequently, the macroeconomic effects of corporate debt are receiving greater attention (Brunnermeier and Krishnamurthy, 2020).

The lessons from the Global Financial Crisis are not easily transferable. Back then, weakly capitalized banks and stressed household balance sheets were key reasons for the depth of the recession and the slow recovery after 2008 (Mian and Sufi, 2010; Jordà, Schularick, and Taylor, 2013). Households saddled with mortgage debt needed time to repair their balance sheets following the housing crash. This time the risks are on the corporate side, raising a different set of questions about the macroeconomic effects of past debt accumulation. Does the evidence from the past provide any useful lessons?

We ask in this paper if large build-ups of corporate debt foreshadow deeper and more protracted recessions, similar to what happens after household debt booms (Mian, Sufi, and Verner, 2017). In order to answer this question, we assemble a new long-run dataset covering business lending by banks and financial markets in 17 advanced economies since the 19th century. For the pre-WW2 period we mainly have data for bank lending to the business sector, although, where possible, we have been able to augment this with corporate bond

\footnotetext{
${ }^{1}$ Throughout this paper, we will use "business debt" and "corporate debt" interchangeably to refer to total debt of the non-financial corporate and non-corporate sectors.
} 
market data. ${ }^{2}$ For the post-WW2 period, we rely on bank lending from the Macrohistory Database (Jordà, Schularick, and Taylor, 2017), hand-collected data from Müller (2018), as well as financial accounts and BIS data that capture the growing importance of nonbank lending channels. 3 Using this data set and modern local projection methods, we investigate how past corporate credit growth booms, in contrast to household debt booms, shape cyclical outcomes.

The empirical literature on corporate debt overhang is mixed. Recent studies with European firm-level micro data such as Kalemli-Özcan, Laeven, and Moreno (2020) and Popov, Barbiero, and Wolski (2018) find conflicting evidence with respect to the investment level and efficiency effects of high debt. Inevitably, post-2008 data are tinted by the financial crisis (Giroud and Mueller, 2017; Kuchler, 2020; Botta, 2020). During this period, investment may have fallen, not due to overhang, but because impaired banks and other intermediaries constricted the supply of credit to preserve capital (Chodorow-Reich, 2014). Lang, Ofek, and Stulz (1996) make a direct empirical link to debt overhang, arguing that lenders cautiously reduce credit supply if they perceive investment opportunities of levered firms to be bleak. This can curb firm growth together with, but in principle independent of, shareholders' incentive to underinvest.

Our empirical analysis paints a consistent picture instead: in aggregate, there is no evidence that corporate debt booms result in deeper declines in investment or output, nor that the economy takes longer to recover than at other times. The growth of corporate credit during the expansion, the level, and their interaction provide no information about how the recession and the recovery will turn out to be.

Our findings echo a venerable theoretical literature. In some models, high levels of debt may also have positive effects on recession trajectories. For example, under limited liability, indebted firms might also have an incentive to gamble on otherwise unrealized risky projects (Admati, Demarzo, Hellwig, and Pfleiderer, 2018). Moreover, when equity holders have superior information about the economic value of assets, high-value firms are less likely to issue new equity as the market tends to underprice it. However, under-investment can then be prevented by debt issuance (Myers and Majluf, 1984). That is, high debt levels indicate prudent past investment whose after-effects might counteract the adverse effects of debt overhang at the macro level.

If corporate credit booms have little effect on the recovery, do they make the economy more fragile, subject to infrequent but large loses? Like Adrian, Boyarchenko, and Giannone (2019); Adrian, Grinberg, Liang, and Malik (2018), we investigate how corporate debt

\footnotetext{
${ }^{2}$ Our data cover, if available, debt liabilities of all businesses. In most countries, the share of non-corporate business debt is a small fraction of corporate debt. See the data section below.

${ }^{3}$ The historical data are available at www.macrohistory.net/data.
} 
buildups affect an economy's tail risk. We measure tail risk using quantile local projections (see, e.g., Linnemann and Winkler, 2016; Loria, Matthes, and Zhang, 2019; Stolbov and Shchepeleva, 2020). Again, we find no evidence that this is the case in contrast to noncorporate, non-financial credit booms, as Adrian, Boyarchenko, and Giannone (2019) and Adrian, Grinberg, Liang, and Malik (2018) also report. Though striking, these results are consistent with the earlier work of Giesecke, Longstaff, Schaefer, and Strebulaev (2014), which focused more narrowly on corporate bonds, and found that default events were only weakly correlated with business downturns over 150 years of U.S. history.

On the household side, recent research points to the prolonged economic drag after household lending booms (Mian, Sufi, and Verner, 2017), and the potentially large effects of household bankruptcy and debt restructuring (Auclert, Dobbie, and Goldsmith-Pinkham, 2019). So why do corporate debt build-ups have negligible consequences for the macroeconomy, and what makes them different from household debt booms?

On the corporate side, the situation is generally more favorable to a swift resolution of financial distress for two reasons. First, if the going concern value of the firm is greater than the market value of assets, both owners and creditors gain from successful restructuring or reorganization (Fama, 1978; Aivazian and Callen, 1980). There are clear incentives for both to restructure the debt. 4 Yet coordination frictions among many dispersed creditors, hold-out problems, asymmetric information, weak contract enforcement and other frictions can make such renegotiation difficult or even prevent it (Gertner and Scharfstein, 1991; Philippon, 2010). The larger such frictions are, the more sand in the wheels of the process and the greater the economic cost.

Second, firm liabilities are ultimately limited by firm assets. When the going concern value of a firm drops below the market value of assets, liquidation of the firm will ensue, the excess debt will be erased, and the assets freed up for other productive ends. Yet the liquidation process too can be more or less inefficient. Poor creditor rights protection, or costly legal procedures can discourage or delay liquidation. These costs will affect the behavior of lenders at the margin, making them more likely to avoid the losses and keep insolvent zombie firms afloat (Caballero, Hoshi, and Kashyap, 2008). Inefficient liquidation increases the survival probability of zombie firms and their importance at the macro level.

\footnotetext{
4The possibility of underinvestment provides an incentive for owners and creditors to restructure debt. Underinvestment pushes the value of the firm below its potential, so that both sides could in principle buy out the other party and gain from implementing the efficient investment policy (Fama, 1978). Bergman and Callen (1991) argue that "running down assets" through underinvestment constitutes a credible and effective threat to bring creditors to the negotiation table. Other theoretical work has qualified underinvestment effects. Berkovitch and Kim (1990) discuss a range of contractual options for credit agreements to address problems of underinvestment. Diamond and He (2014) emphasize maturity structure. Repeated interaction with creditors may provide firms with an incentive to invest prudently even under debt overhang, since a reputation for maximizing firm value and minimizing default risk will lower risk premia (John and Nachman, 1985).
} 
Ultimately, corporate financial stress will inflict economic costs to the extent that restructuring or liquidation frictions lead to deviations from the canonical Modigliani and Miller (1958) model. Our empirical results indicate that these frictions are less prevalent on the corporate side than the factors preventing balance sheet reorganization after household debt booms. As noted by Auclert, Dobbie, and Goldsmith-Pinkham (2019), individual banks have no interest in restructuring household debt as such policies are beneficial only on the macro level. For corporate debt, incentives for owners and creditors are often aligned, and the question is if frictions impede efficient restructuring or liquidation. We can therefore go one step further and look for evidence in the data that differences in such frictions affect economic outcomes. The more we move away from a frictionless Modigliani and Miller (1958) world, the more pronounced the debt overhang problem can be expected to become.

To confront this question, we build on Djankov, McLiesh, and Shleifer (2007) and Djankov, Hart, McLiesh, and Shleifer (2010) to quantify institutional frictions to corporate debt reorganization or liquidation for a subset of business cycles and corporate credit booms since the 1970s. Moreover, to boost the case that the effects of these institutional differences by themselves matter, we turn to a local projection instrument variable strategy (LP-IV). Specifically, we appeal to the exogenous variation of legal origins in the spirit of La Porta, Lopez-de-Silanes, Shleifer, and Vishny $(1997,1998)$ and La Porta, Lopez-De-Silanes, and Shleifer (2008) as an instrument for the reorganization frictions. The IV strategy delivers an answer-it depends. Where institutions encourage efficient restructuring and liquidation, the drag from business debt booms is small; but in high-friction regimes, the pace of recovery can be dragged down significantly.

One can summarize the policy implications of our analysis as follows. Frameworks that efficiently facilitate the restructuring of debt or liquidation reduce the macroeconomic fallout of corporate debt booms. In contrast, more frictions lead to more underinvestment and survival of zombie firms, which can impair aggregate productivity growth and slow down the recovery after recessions (Caballero, Hoshi, and Kashyap, 2008; McGowan, Andrews, Millot, and Beck, 2018).

We begin the paper by first introducing the dataset. Based on the new data, we then study how corporate credit booms affect business cycle dynamics. We complement this analysis by studying how corporate debt booms affect the economy's tail risks. To find out what explains our results to that point, we then analyze how restructuring costs affect corporate debt overhang. We conclude by summarizing our findings and providing some policy relevant observations. 


\section{DAtA DESCRIPTION}

The basis for the analysis is a novel long-run dataset on business credit, including bond market debt and credit from non-bank intermediaries, covering 17 advanced economies since the nineteenth century. 5

Specifically, for the pre-WW2 period we have been able to construct separate series for business debt for 9 countries. Data for the U.S. start in 1916 and build on the business sector debt data calculated by James and Sylla (2006), from which we deduct debt obligations of financial institutions. For other countries, we calculate bank credit to the non-financial business sector based on the assets of specialized commercial banks that provide loans to business and other corporate financing. As an example, for Germany we sum loans and advances extended to non-banks by joint-stock industrial banks as well as commercial credit unions. We identify similar proxies for business credit in other countries, as detailed in the appendix. The new data complement the long-run dataset in Jordà, Schularick, and Taylor (2017), from which we take data on household bank credit as well as a long list of macroeconomic controls, updated to 2019.

After WW2, we rely on comprehensive measures of business credit provided by the financial accounts and the Total Credit Database assembled by the Bank of International Settlements (BIS). ${ }^{6}$ These include secured and unsecured debt obligations of all maturities and from all types of lenders in addition to conventional bank lending contracts. Additional financial accounts data on non-financial business liabilities come from the OECD and Eurostat databases and individual publications such as Bonci and Coletta (2012) for Italian data, Roe (1971) and Office for National Statistics (2016) for U.K. data, and Deutsche Bundesbank (1983) and Deutsche Bundesbank (1994) for German data. All postwar U.S. data are from the Fed's financial accounts (Board of Governors of the Federal Reserve System, 2020).

As noted earlier, we use the terms "business debt" and "corporate debt" interchangeably throughout the paper to refer to all debt liabilities of all firms, whether corporate or non-corporate. Whenever available, our series include the debt liabilities of non-corporate businesses as well. Historical sources do not always allow for a clean separation of the two. Corporate debt is the dominant component. In the U.S., non-corporate businesses account for only one third of total non-financial business debt outstanding.

In total, there are 1,717 country-year observations for business sector debt, 480 of which correspond to the pre-WW2 period. The individual series are plotted in the the appendix,

\footnotetext{
5The 17 advanced economies are the U.S., Japan, Germany, France, U.K., Italy, Canada, Netherlands, Belgium, Sweden, Australia, Spain, Portugal, Denmark, Switzerland, Finland, Norway.

${ }^{6}$ For details on its construction see Dembiermont, Drehmann, and Muksakunratana (2013).
} 
Figure 1: Business credit/GDP since 1870

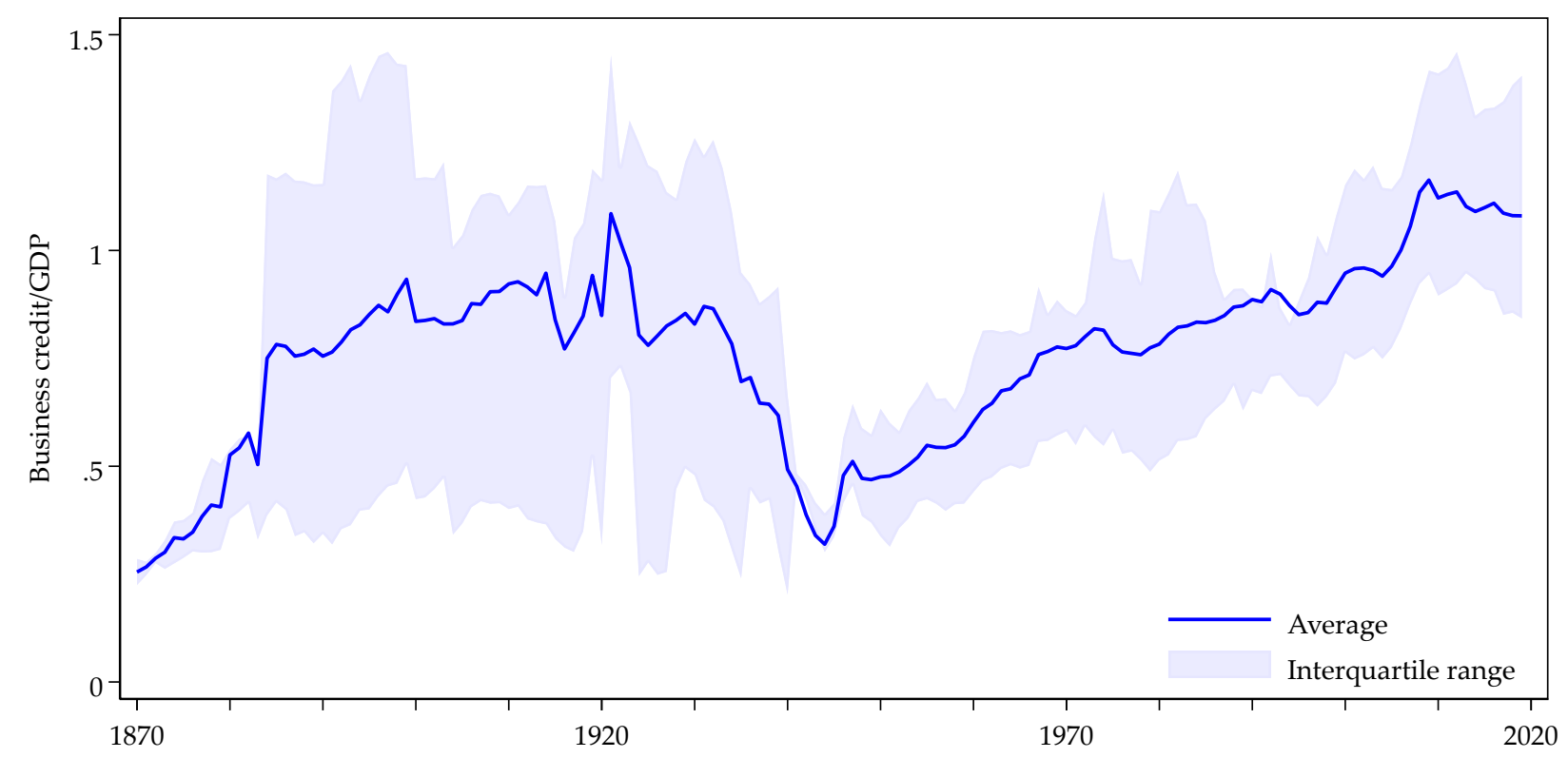

Notes: The figure shows non-financial business credit over GDP for our sample of 17 advanced economies. Interquartile range shown as the shaded region. See text.

which also describes details of the construction and underlying sources, including the materials kindly shared by Müller (2018). The results presented in the paper always use the entire dataset, excluding the wartime years of WW1 and WW2. All findings are qualitatively and quantitatively similar when restricting the data to the post-WW2 period. For brevity, we place these results in the appendix for the interested reader.

In corporate finance, the term "leverage" often refers to the ratio of debt to equity. However, we will instead focus on the ratio of corporate debt to GDP. The reason is that several of the episodes that we will investigate involve sudden and dramatic repricing of assets. Thus, debt and equity could both be shifting at the same time, making the traditional definition of leverage harder to interpret. By taking the ratio of debt to GDP, one can think of it as a cash-flow based measure of leverage and hence we will often just denote this ratio as leverage.

Figure 1 shows the evolution of business credit over the full sample, which starts in 1870. The figure plots the cross-country median and the inter-quartile-range of business credit relative to GDP-our measure of leverage. Historically, business credit has ranged between $50 \%$ and $100 \%$ of GDP for most advanced countries. The series trends up before WW1, before entering a period of high volatility in the interwar years, followed by a sharp reduction during WW2. Since then, business credit has doubled from about $50 \%$ to $100 \%$ of GDP today. Many countries are currently at their highest level in the past 150 years. 
Another aspect of our empirical strategy requires that we identify business cycle turning points. Here we follow Jordà, Schularick, and Taylor (2013) and use the Bry and Boschan (1971) algorithm for all countries. At annual frequency and for the U.S., this algorithm reproduces almost exactly the NBER's dating. Briefly, the Bry and Boschan (1971) algorithm dates turning points as local maxima and minima of real GDP per capita data in levels. Minima are labeled as troughs and maxima as peaks. Recessions go from peak to trough, expansions from trough to peak.

Finally, we further separate recessions into two types. We will refer to financial recessions as those associated with a financial crisis in a \pm 2 year window around a peak. The rest are denoted normal recessions. The financial crisis chronology itself is based on the latest version of the Jordà, Schularick, and Taylor (2017) Macrohistory Database. ${ }^{7}$

\section{Do LARGE BUSINESS CREDIT EXPANSIONS MAKE RECESSIONS WORSE?}

For motivation, we first consider first how business and household credit build-ups during the expansion correlate with the severity of the recession and the speed of the recovery. As a first pass the easiest thing is to plot, for each of the 150 business cycles in our dataset, the scatter of two-year GDP per capita log-difference in the first two years of the recession (from peak year $t$ to $t+2$ ) against the five-year change in business credit relative to GDP in the preceding 5 years before the peak (from $t-5$ to $t$ ). This is presented in Figure 2, which shows that there is no relationship between the two: that is, the depth of the recession does not depend on how much business credit grew in the preceding expansion.

Figure 2 is persuasive, but it is too crude in at least two respects. First, it is interesting to see how the trajectory of the recession is affected by business credit. Do we fail to see a relationship because high growth of business credit leads to shallower but longer-lasting recessions? Or perhaps recessions are deeper but with quicker recoveries? Or is it that recessions come in all shapes and sizes that have nothing to do with business credit? Second, we may wonder whether the scatter plot is confounded by effects coming from factors other than business credit, which would require controlling for macroeconomic aggregates observed before the start of the recession.

We solve these two issues by estimating the cumulative change in real GDP per capita from the start of the recession to $h$ periods thereafter using local projections. In particular, let $y_{i t}$ denote log real GDP per capita, multiplied by 10o, observed for country $i$ at time $t$. Our interest on the trajectory of recessions/recoveries means that we will focus on those time periods associated with a peak in economic activity and denoted $p=1, \ldots, P$ where the

\footnotetext{
7http://www.macrohistory.net/data/.
} 
Figure 2: Business credit expansions and recession severity

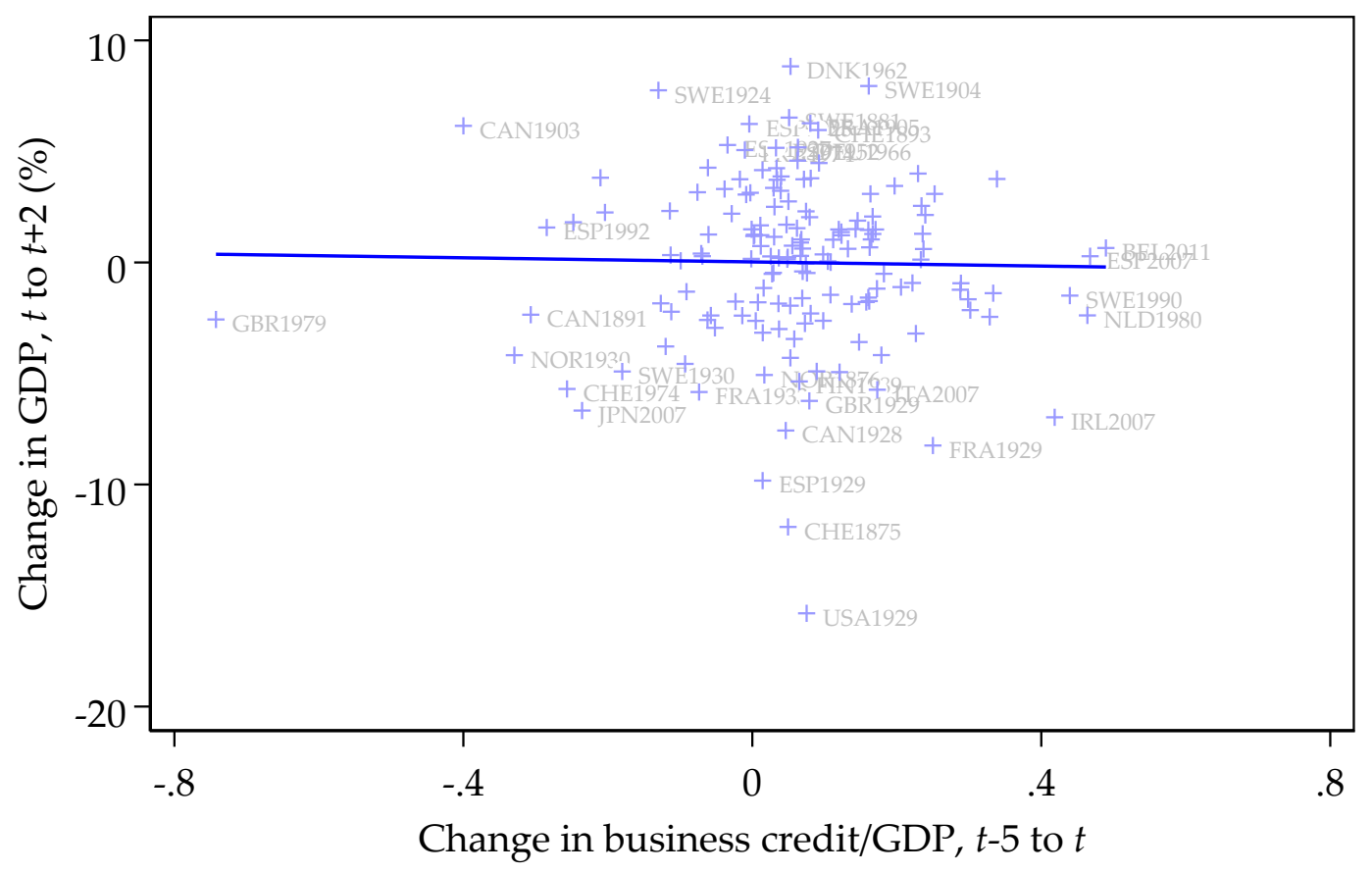

Notes: The figure provides the scatter plot and regression fit line of 2-year real GDP per capita growth after business cycle peaks against business the change in the credit/GDP ratio in the preceding 5 years. Each point is a cyclical peak or start of a recession. See text.

index is understood to be specific to each country and hence it is not expressly indicated to avoid cluttered notation. Hence, we denote by $t=t(p)$ the time period associated with the $p^{\text {th }}$ recession peak.

Thus, the outcome variable $y_{i t(p)+h}-y_{i t(p)}$ will (approximately) measure the cumulative percentage change in real GDP per capita, $h$ horizons after the peak $p$, where we will display responses up to 5 years out. Using similar notation, $\Delta_{5} x_{i t(p)}^{j} \equiv x_{i t(p)}^{j}-x_{i t(p)-5}^{j}$, for $j=B, H$, denotes the 5 -year change in Business, $B$, or Household, $H$, debt measured as a ratio to GDP. Hence, these variables are predetermined once the recession starts. In addition, the vector $w_{i t(p)}$ summarizes all other macroeconomic variables observed before the start of the recession. This vector includes the current plus two lagged values of real GDP growth, inflation, real investment growth, short-term interest rates on government debt, real household credit growth, and real business credit growth.

We make one remark. If, under the null, the history of medium-term credit growth did not matter then the last two credit variables listed above and their lags should be adequate controls, and should leave no explanatory power for our main variables of interest $\Delta_{5} x_{i t(p)}^{j}, j=B, H$. This is intentional: we set ourselves a higher hurdle over which to show that recession/recoveries after sustained credit booms are different. 
With these variable definitions, we estimate the following local projections (Jordà, 2005):

$$
y_{i t(p)+h}-y_{i t(p)}=\alpha_{h}+\alpha_{h i}+\beta_{h}^{B} \Delta_{5} x_{i t(p)}^{B}+\beta_{h}^{H} \Delta_{5} x_{i t(p)}^{H}+\gamma_{h} w_{i t(p)}+\epsilon_{i t(p)} \quad \text { for } h=1, \ldots, 5,
$$

where $\alpha_{h i}$ are country-fixed effects normalized to sum to zero so that $\alpha_{h}$ is the average percentage change in real GDP per capita after a peak since we demean all regressors by their full-sample averages. ${ }^{8}$ The coefficients of interest are $\beta_{h}^{j}$ for $j=B, H$, each indicating how the expected future path of real GDP per capita varies with the behavior of credit (in the business and household sectors) during the expansion.

We do not interpret the coefficients $\beta_{h}^{j}$ for $j=B, H$ causally since our interest is in comparing the typical trajectory in a recession/recovery given the behavior of business versus household credit in the preceding expansion. That said, the predetermined nature of our variables of interest and our rich set of controls reduce the chances that the differences could be explained by other factors.

\subsection{Baseline results}

Table I presents estimates of $\alpha_{h}, \beta_{h}^{B}$, and $\beta_{h}^{H}$ from our main specification.9 Based upon these coefficient estimates, Figure 3 plots predicted trajectories or responses for the average recession as well as recessions preceded by a two-standard-deviation (above mean) expansion of business credit. The peak year is normalized to zero and deviations in subsequent years are measured in log points times 100 (approximate percentage changes). For comparison, we also show the responses for a corresponding two-standard-deviation expansion of household credit. For household credit-to-GDP expansions $\Delta_{5} x_{i t(p)}^{H}$, two standard deviations amount to 34 percentage points. The corresponding figure for business credit-to-GDP expansions $\Delta_{5} x_{i t(p)}^{B}$ stands at 14.4 percentage points.

The results paint a clearer picture than Figure 2. The table presents formal tests, but Figure 3 makes it unequivocal that the effects of past corporate credit booms (especially once controlling for other macroeconomic aggregates) are negligible-in the economic and statistical senses-as compared to household credit booms. Recessions preceded by household credit expansions are not only deeper, but are followed by significantly slower recoveries. These findings are very much consistent with the existing evidence in Jordà, Schularick, and Taylor (2013); Reinhart and Rogoff (2014); Bordo and Haubrich (2017), for example.

\footnotetext{
${ }^{8}$ Applying the within transformation but adding sample means on both sides of the equation allows OLS to estimate $\alpha_{h}$. Demeaning LHS regressors by sample averages prior to estimation yields the desired interpretation.

${ }^{9}$ Unconditional results are shown in appendix Table A.14.
} 
Table 1: Credit booms and business cycle responses: local projections, with macro controls

Dependent variable: Change in real GDP per capita since peak $(\log \times 100)$

\begin{tabular}{lccccc}
\hline \hline & $(1)$ & $(2)$ & $(3)$ & $(4)$ & $(5)$ \\
& $h=1$ & $h=2$ & $h=3$ & $h=4$ & $h=5$ \\
\hline Average cycle $\alpha_{h}$ & $-1.66^{* * *}$ & $-1.09^{* * *}$ & $0.36^{* *}$ & $1.88^{* * *}$ & $3.95^{* * *}$ \\
& $(0.08)$ & $(0.14)$ & $(0.17)$ & $(0.24)$ & $(0.34)$ \\
Business credit/GDP expansion $\Delta_{5} x_{i t(p)}^{B}$ & 0.25 & 2.14 & -0.68 & 0.17 & 2.75 \\
& $(1.13)$ & $(1.56)$ & $(2.38)$ & $(3.81)$ & $(4.21)$ \\
& & & & & \\
Household credit/GDP expansion $\Delta_{5} x_{i t(p)}^{H}$ & -5.05 & $-22.04^{* * *}$ & $-32.90^{* * *}$ & $-43.60^{* * *}$ & $-40.99^{* * *}$ \\
& $(3.97)$ & $(4.73)$ & $(5.55)$ & $(8.80)$ & $(9.05)$ \\
Macro controls & Yes & Yes & Yes & Yes & Yes \\
\hline$\beta_{h}^{B}=\beta_{h}^{H}$ (p-value) & 0.213 & 0.000 & 0.000 & 0.000 & 0.000 \\
$R^{2}$ & 0.15 & 0.35 & 0.41 & 0.44 & 0.48 \\
Cycles & 150 & 150 & 150 & 150 & 149 \\
\hline \hline
\end{tabular}

Notes: Within-estimator, standard errors clustered on countries in parentheses. ${ }^{* * *} \mathrm{p}<0.01,{ }^{* *} \mathrm{p}<0.05,{ }^{*} \mathrm{p}<$ o.1. Credit expansion denotes past 5-year change in credit/GDP ratio.

Figure 3: Business and household credit, average and $+2 S D$ responses

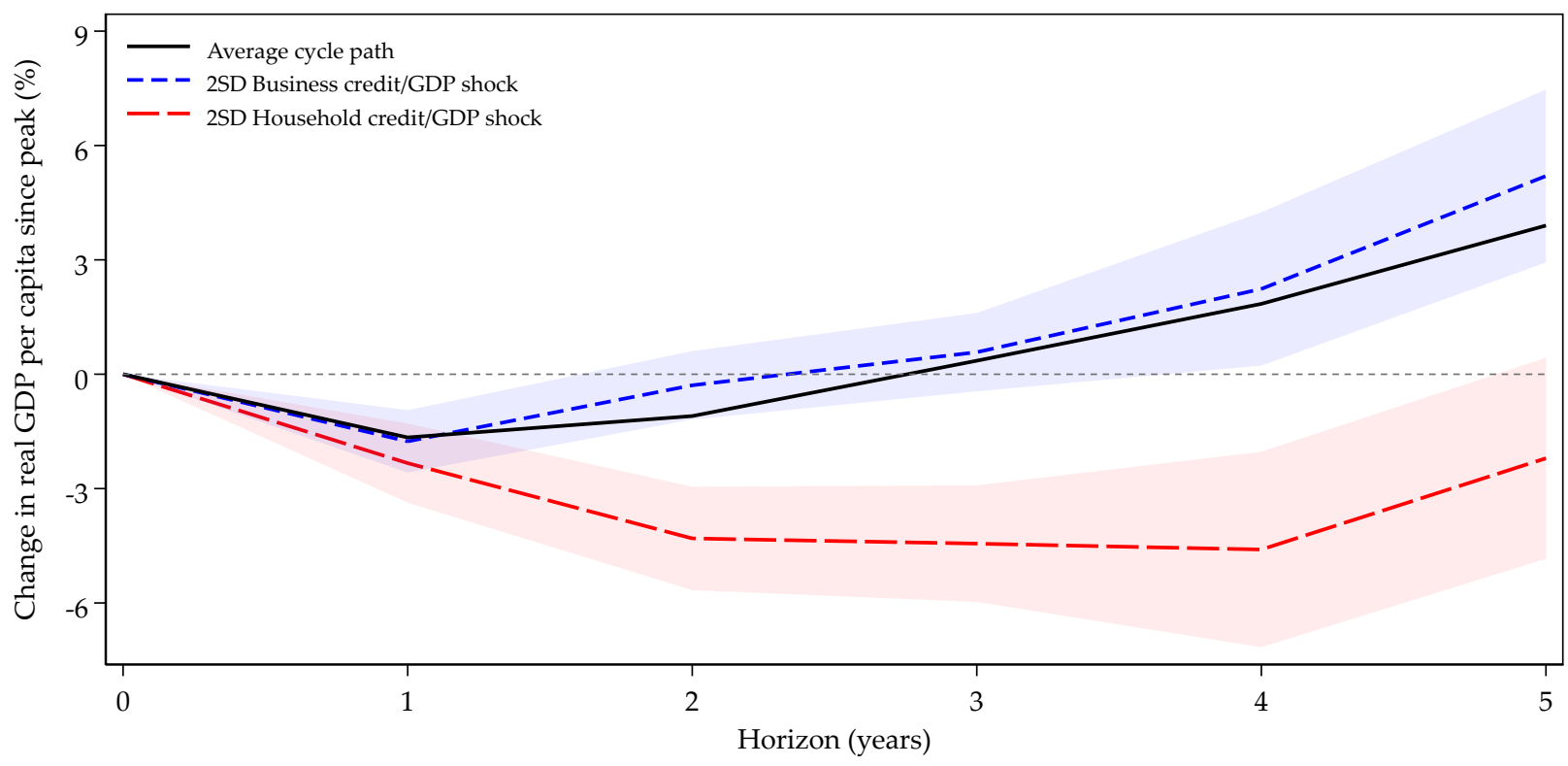

Notes: Figures show the predictive effects on growth of a two-SD credit expansion in the five years preceding the recession for business credit booms (left panels) and household credit booms (right panels). Estimates based on all business cycles in 17 advanced economies since 1870 . Standard errors are clustered at the country level. Shaded areas denote the $95 \%$ confidence interval. See text. 
To provide some texture to these results, a 1o percentage points (pps) increase in the business credit/GDP ratio in the expansion-a considerable rate of growth by historical standards-is associated with a mildly slower recovery. After 5 years from the start of the recession, GDP per capita is 3.9\% higher rather than the $4.5 \%$ observed in more normal times. In contrast, a to pps increase in household debt in the expansion is associated with dire consequences. The economy barely recovers the level it had at the start of the recession 5 years later. Formal Wald tests confirm that the coefficients on business and household credit in these local projections are significantly different from one another starting in year two.

These results are robust to introducing linear and quadratic time trends as well as to the exclusion of all recessions after 2007, when many of the countries in our sample experienced the Global Financial Crisis. Moreover, we examine alternative definitions of our measure of credit booms during the expansion preceding the recession. In particular, we looked at three (instead of five) year changes in credit/GDP, three (or five) year growth of real credit, and the measure proposed by Jordà, Schularick, and Taylor (2013). All corresponding estimates are tabulated in the appendix.

\subsection{Corporate debt and financial crises}

Jordà, Schularick, and Taylor (2013) showed that the more credit built up in the expansion, the deeper the recession and the slower the recovery, in both normal and financial crisis recessions. Here we investigate whether it matters what type of credit build up takes place, business versus household credit, and whether it matters more in financial crises. We investigate these issues by stratifying the local projections reported in the baseline case as follows. We classify recessions into two bins as above: "financial" recessions defined as recessions where a financial crisis occurs within a two-year window, and all other recessions labeled as "normal" recessions. We then examine how each type of credit build-up, business versus household, affects the subsequent response path in each type of recession, and with or without credit booms.

Figure 4 presents the results of this analysis. Here, panel (a) shows the results for business credit, and panel (b) for household credit. In both cases, as is well-known, financial recessions are deeper and last longer than normal recessions. The effect of a business credit boom (characterized by credit growth two standard deviations above the mean, as before) is essentially zero, economically and statistically speaking. The trajectories do not change one way or the other. In contrast, the effects are much more sizable when we look at household credit. A credit boom during the expansion (again, measured by credit growing two standard deviations above the mean) makes either type of recession 
Figure 4: Business and household credit, normal versus financial recessions, average and $+2 \mathrm{SD}$ responses
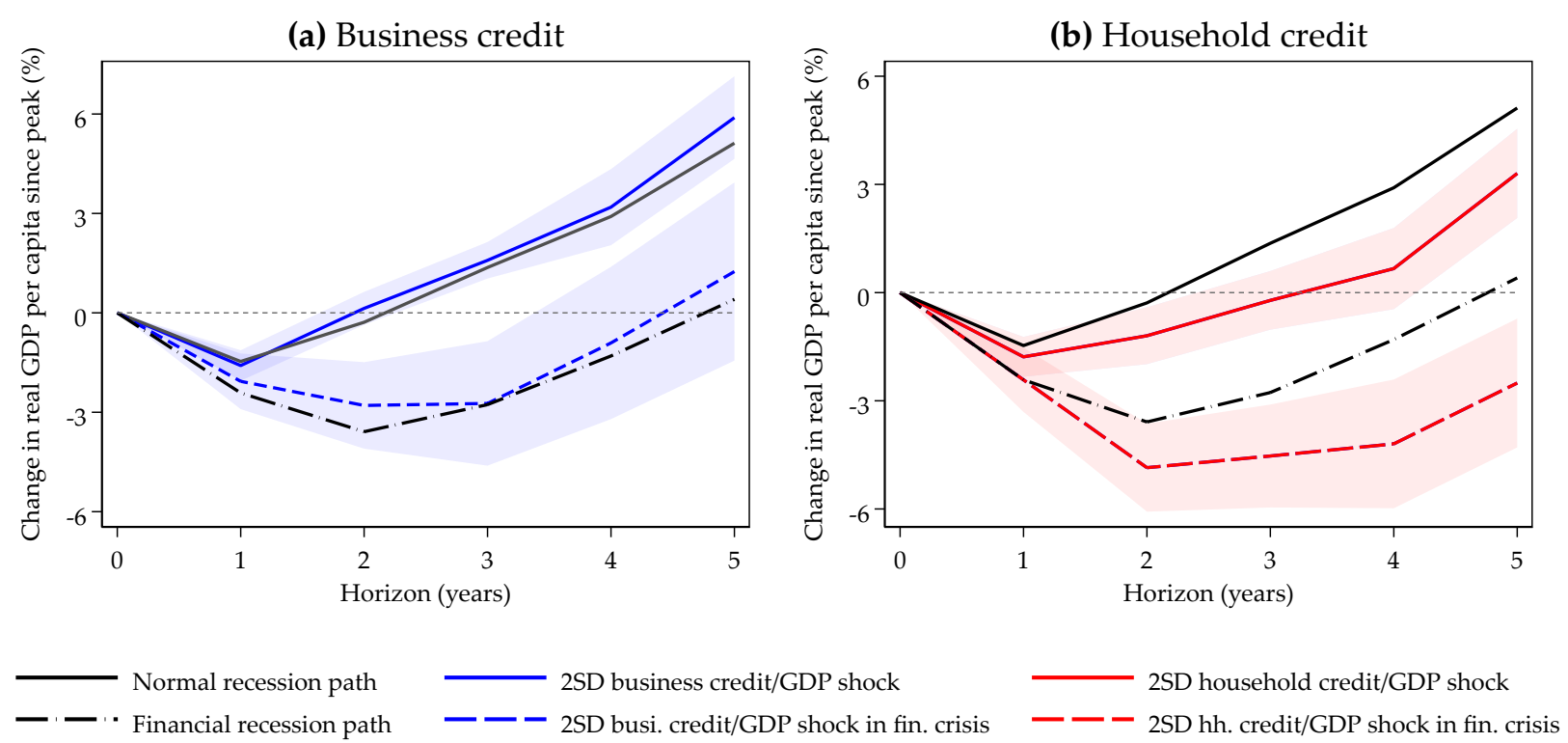

Notes: Local projections stratified by type of recession. Left panel displays average and two SD business credit growth paths, right panel displays the same figure but for household credit. All regressions include the full set of macro controls and country fixed effects. Standard errors clustered by country. Shaded areas denote the $95 \%$ confidence interval. See text.

worse economically speaking. The effects may even be somewhat larger in a financial crisis, although the uncertainty bands are large enough to prevent any forceful conclusions on this issue.

\subsection{The macroeconomic effects of credit booms}

We have seen how debt booms relate to the business cycle as measured by real GDP per capita. In this section we investigate a variety of other macro-financial variables. This should give us a better sense of the underlying channels.

Using a similar approach to Figure 3, in Figure 5 we display the responses of other key indicators, as follows. Panels (a) and (b) of Figure 5 show the responses of real consumption and real investment per capita, two important components of GDP. Panels (c) and (d) display the unemployment rate and inflation, respectively, two key variables in any analysis of monetary policy. Panels (e) and (f) display the evolution of real household and business credit to get a sense of frictions that may impede the recovery and hence justify the dynamics that we observe for GDP. Finally, panels $(\mathrm{g})$ and $(\mathrm{h})$ show predictions for asset prices. ${ }^{10}$

\footnotetext{
${ }^{10}$ All local projections underlying the figures are presented in tabular form in the appendix. They include the full set of macro economic controls. The left-hand side variable, as before, refers to the cumulative change since the cycle peak. All experiments refer to a credit boom 2 standard deviations above the historical mean.
} 
Generally speaking, corporate credit booms do not depress aggregate demand-whether consumption, or more interestingly, investment. This is in stark contrast to a household credit boom, whose effects are particularly visible in investment. A possible explanation as to why investment is relatively insensitive to a corporate boom is that firms may shift to other internal sources of financing, i.e., equity instead of debt. Covas and Den Haan (2011) document that for large firms, equity issuance is countercyclical while debt take-up is procyclical. Another alternative explanation is that, although business credit declines (as shown in panel (e)), lower business credit may simply reflect debt restructurings and haircuts since our data are aggregated.

The effects on the unemployment rate and inflation are consistent with the behavior of consumption and investment, though they are measured more imprecisely. Nevertheless, a credit boom generally results in higher unemployment and lower inflation than in the average recession. Thus, a recession that follows a boom in credit, especially household credit, appears to require stronger monetary support with apparently little cost to inflation.

Panels (e) and (f) of Figure 5 show the aftermath in credit markets. Echoing Jordà, Schularick, and Taylor (2013), household credit booms are followed by a long period of household deleveraging, which in turn is consistent with depressed aggregate demand, as panels (a) to (d) indicate. Business credit also grows significantly slower after business credit booms, requiring a similar period of financial repair. And this is true even if the boom takes place in the household sector. The same cannot be said as strongly for household credit. A business credit boom has much less effect on it, and it recovers more rapidly.

Finally, we investigated asset price behavior, reported in panels (g) and (h). We find that both house and stock prices are more negatively affected after household credit booms as compared to business credit booms. Declining housing wealth and falling residential investment seem to have been an important catalyst for the toxic general equilibrium spiral of household credit reported by Mian and Sufi (2010) for the U.S. after 2008.

\section{TAIL RISKS: QUANTILE LOCAL PROJECTIONS}

In the second of the three main questions we set out to answer-Does corporate debt make severe recessions dramatically worse?-we take inspiration from recent research by Adrian, Boyarchenko, and Giannone (2019) and Jordà, Schularick, and Taylor (2020). They suggest that GDP growth exhibits fat-tailed behavior, that is, the lower quantiles of the GDP growth distribution contain potentially extreme losses. Recall that earlier we found no evidence of corporate debt overhang, on average. Thus, to investigate whether corporate debt makes the worst recessions have very extreme declines, we estimate quantile local projections (see, 
Figure 5: Business and household credit, responses of various macro-financial variables

(a) Real consumption p.c.
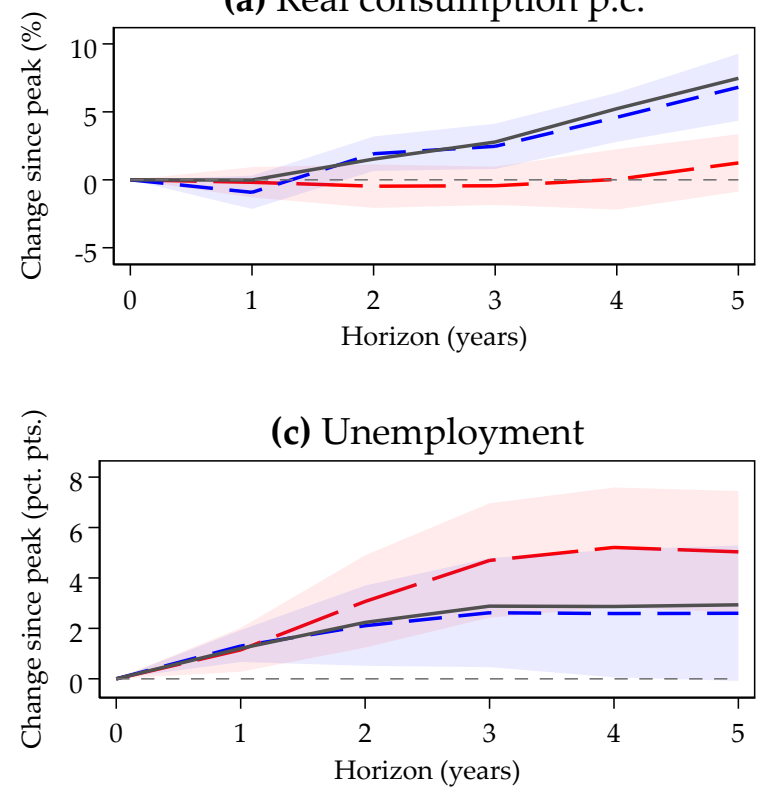

(e) Real household credit

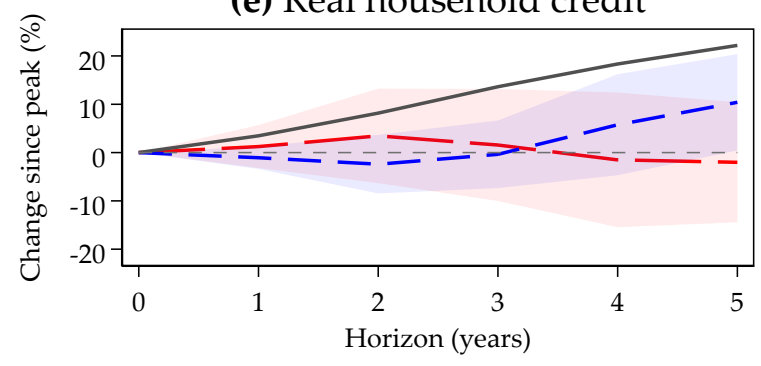

(g) Real house prices

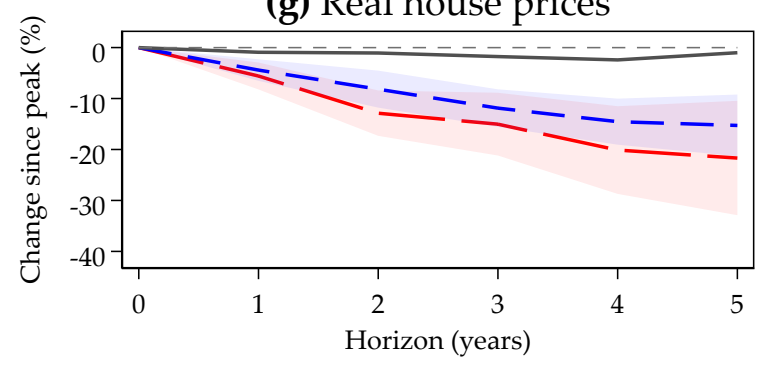

(b) Real investment p.c.

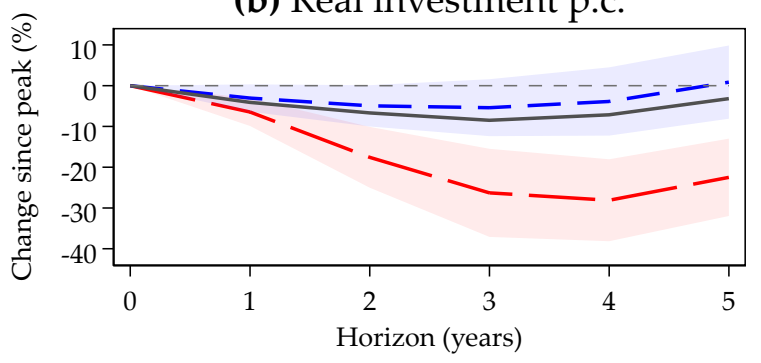

(d) CPI

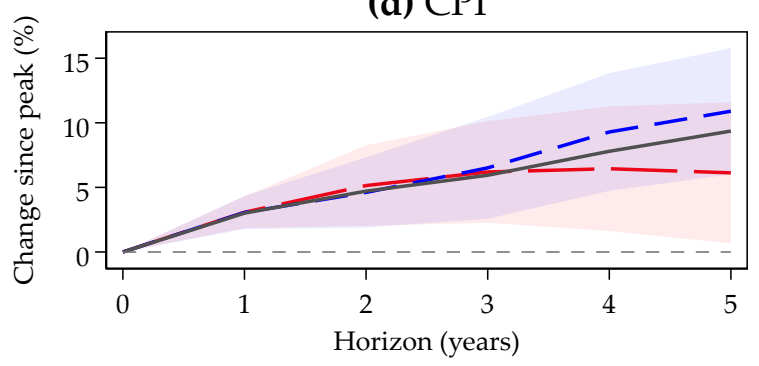

(f) Real business credit

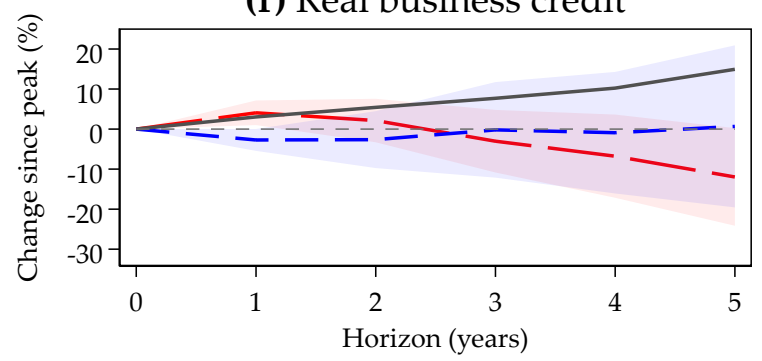

(h) Real stock prices

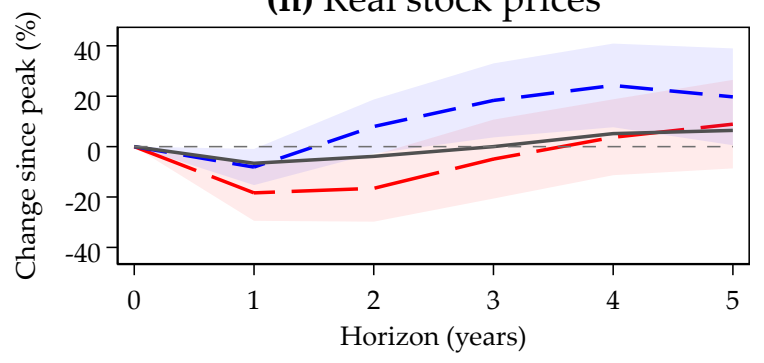

- Average cycle path _ - - 2SD Business credit/GDP shock

2SD Household credit/GDP shock

Notes: The figure shows responses to a two-SD credit expansion in the five years preceding the recession for business credit booms on the left and household credit booms on the right of each panel. The sample includes all business cycles in 17 advanced economies since 1870. Standard errors clustered at the country level. Shaded areas denote the $95 \%$ confidence interval. See text. 
e.g., Linnemann and Winkler, 2016; Adrian, Boyarchenko, and Giannone, 2019; Stolbov and Shchepeleva, 2020). Specifically, we examine how corporate debt affects the distribution of GDP per capita growth conditional on observables.

Denote $\Delta_{h} y_{i t(p)+h}=y_{i t(p)+h}-y_{i t(p)}$, that is, the approximate cumulative growth rate of GDP per capita using the same notation of the previous section. Let $\boldsymbol{X}_{i t(p)}$ collect the credit growth variables defined earlier $\left(\Delta_{5} x_{i t(p)}^{j}, j=B, H\right)$, as well as the vector of macro controls, $w_{i t(p)}$, the constant, and the fixed effects. Given this setup, quantile local projections can be estimated based on

$$
\begin{aligned}
\hat{\boldsymbol{\theta}}_{h, \tau}=\underset{\boldsymbol{\theta}_{h, \tau}}{\operatorname{argmin}} \sum_{1}^{t(P)}(\tau & \mathbb{1}\left(\Delta_{h} y_{i t(p)+h} \geq \boldsymbol{X}_{i t(p)} \boldsymbol{\theta}_{h, \tau}\right)\left|\Delta_{h} y_{i t(p)+h}-\boldsymbol{X}_{i t(p)} \boldsymbol{\theta}_{h, \tau}\right| \\
& \left.+(1-\tau) \mathbb{1}\left(\Delta_{h} y_{i t(p)+h}<\boldsymbol{X}_{i t(p)} \boldsymbol{\theta}_{h, \tau}\right)\left|\Delta_{h} y_{i t(p)+h}-\boldsymbol{X}_{i t(p)} \boldsymbol{\theta}_{h, \tau}\right|\right),
\end{aligned}
$$

where $\mathbb{1}($.$) denotes the indicator function and \tau \in(0,1)$ indicates the $\tau^{\text {th }}$ quantile. The quantile of $\Delta_{h} y_{i t(p)+h}$ conditional on $\boldsymbol{X}_{i t(p)}$ is then given by

$$
Q\left(\Delta_{h} y_{i t(p)+h} \mid \boldsymbol{X}_{i t(p)}\right)=\boldsymbol{X}_{i t(p)} \boldsymbol{\theta}_{h, \tau} \equiv q_{\tau, t}^{h}
$$

The coefficients $\boldsymbol{\theta}_{h, \tau}$ measure the effect of the right-hand side variables on the $\tau$ quantile of the conditional distribution of $\Delta_{h} y_{i t(p)+h}$. Specifically, using notation analogous to that in Equation 1, the coefficient $\beta_{h, \tau}^{B}$ will measure the effect of a corporate debt boom on the conditional distribution of $\Delta_{h} y_{i t(p)+h}$, and similarly for household debt with the coefficient $\beta_{h, \tau}^{H}$. Hence, note that these coefficients will vary depending on the quantile $\tau$ selected.

Our approach to calculating quantile local projections is completely parallel to the way one usually computes local projections at the mean, as we did in Equation 1. The only difference is that we are now dealing with a nonlinear model so the marginal effect of a change in corporate (household) debt has to be evaluated accordingly. However, this simple setup admits these nonlinear effects in an unspecified, flexible manner.

Figure 6 shows how we apply these methods to our data. In particular, we focus on the $20^{\text {th }}$ percentile of the conditional distribution of GDP per capita growth to investigate tail events. We did not choose a smaller quantile so as to have a reasonable sample of data for estimation. The figure displays quantile local projections alongside typical local projections evaluated at the mean. We display two cases, one for corporate debt, and one for household debt booms. These are defined as before, comparing the debt growth at the historical mean against growth at a rate 2 standard deviations above the historical mean. Consider first the figure associated with a corporate debt boom. The marginal effect of a corporate debt 
Figure 6: Business and household credit, responses at $20^{\text {th }}$ percentile of real GDP per capita growth

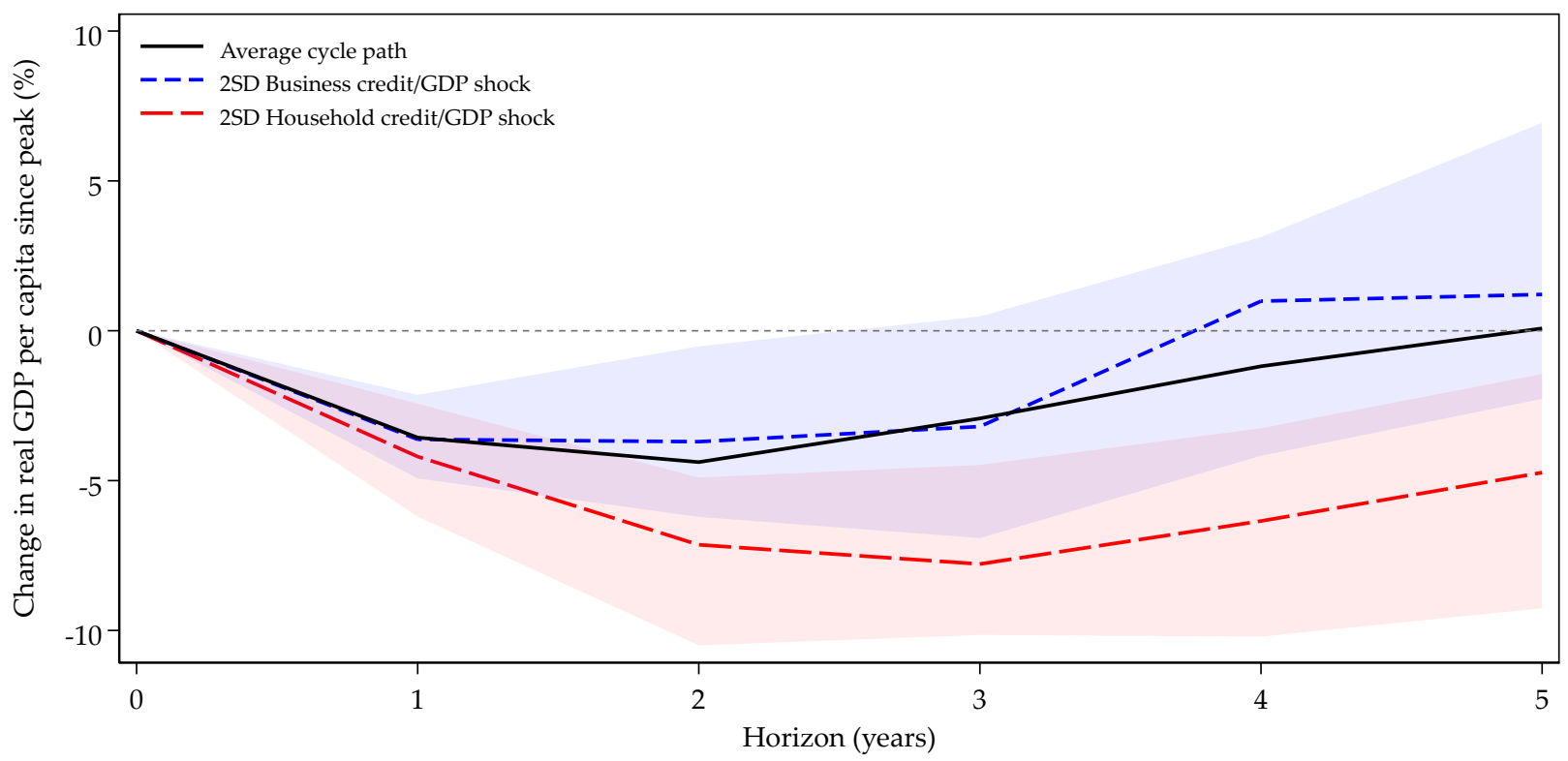

Notes: Figures show the predictive effects on growth of a two-SD business/household credit buildup in the five years preceding the recession based on a LP series of quantile regressions. Business credit booms shown in the left-hand side panel and household credit booms shown in the right-hand side panel. Shaded areas denote the $95 \%$ confidence interval based on bootstrap replications. See text.

boom on the recovery path is the same whether considering the average growth path or the path of the $20^{\text {th }}$ percentile worst recessions. In contrast, a household debt boom of a similar magnitude affects the worst $20^{\text {th }}$ percentile recession paths very differently than the mean path: household debt booms increase the risk of experiencing a bad recession. These results therefore align well with Adrian, Boyarchenko, and Giannone (2019).

\section{INSPECTING THE MECHANISM: THE COSTS OF DEBT RESTRUCTURING}

The analysis thus far highlights a striking dichotomy: household debt booms have much stronger cyclical implications than corporate debt booms. One possible explanation is the legal difference between the two types of debt: household debt is owed by individuals, business debt is owed by abstract legal entities, which makes for different incentive structures (Jensen and Meckling, 1976). The liabilities of businesses are limited by their assets, thereby shielding the wealth of equity holders. Thus, recessions may darken business prospects, but by shrinking assets they effectively reduce business liabilities. In addition, a common desire to protect any "going concern" value of a business acts as a powerful incentive to resolve corporate distress in a reasonable and expeditious manner. And of course, businesses can try to finance through issuing more equity, an option not available to households. Households face a very different environment. In a recession households see incomes 
decline yet their debts remain unchanged. Consumer debt exemptions and protections are hard-coded in the law-if any-and tend to be flimsy (Niemi-Kiesiläinen, 1997; Mitman, 2016). Creditors cannot of course secure a claim to human capital, and recourse provisions can drive the pursuit of recoveries like wage garnishments. Such settlements can take a long time to work out and even longer to fulfill and escape. Here debt overhang can cast a longer, darker shadow. Agarwal, Amromin, Ben-David, Chomsisengphet, Piskorski, and Seru (2016) and Auclert, Dobbie, and Goldsmith-Pinkham (2019), among others, have highlighted the importance of debt relief for aggregate demand management.

An implication from this literature is that efficient debt resolution is crucial to prevent debt overhang and zombie firms following a corporate debt boom. A corollary is that variations in the efficiency of the institutions will modulate the costs of debt booms. The harder it is to restructure debt, the worse the corporate debt overhang is likely to be. Similarly, liquidation with high deadweight costs grow the population of zombie firms at the margin. In this section, we examine these ideas more carefully. We aim to get to a more granular empirical differentiation between a world of Myers (1977) and large-cost liquidation and the frictionless Modigliani and Miller (1958) benchmark view where debt overhang and zombie firms should not arise. While these are substantively firm-level questions, we are interested in tracing out their aggregate macroeconomic implications.

We put these ideas to work with an analysis of the 1978-2019 period by assessing how measures of efficient debt restructuring and business liquidation modulate the responses that we calculated earlier. That is, for a recession preceded by corporate debt built-up, do frictions impeding restructuring and liquidation slow down the recovery? To measure the characteristics of these legal procedures we draw on the creditor rights indicator of Djankov, McLiesh, and Shleifer (2007) which spans the years 1978-2003. This measure codes legal norms regarding creditors' ability to extract-and present owners from channeling offassets in case of bankruptcy. Strong protection of creditor claims reduces the possibility that firms owners can withhold assets in bankruptcy, which would weaken owner's incentives to negotiate a restructuring. Moreover, strong creditor protection decreases liquidation costs for creditors, reducing their incentives to keep zombie firms afloat. We extend this series using World Bank survey data collected using the methodology of Djankov, Hart, McLiesh, and Shleifer (2010) for the later period 2004-2019. They asked practitioners to characterize national insolvency proceedings and reports various measures of legal efficiency. The recovery rate measures the share of debt paid to creditors in the event of default. A high recovery rate reflects both low frictions in restructuring as well as liquidations. ${ }^{11}$

\footnotetext{
${ }^{11}$ The results are very similar when using other indicators provided by the survey: insolvency procedure cost, insolvency procedure time, or two further summary measures-the resolution score and overall strength of the bankruptcy procedure.
} 
To maximize sample size, we seek to combine the two indicators into a single series. To do this, we transform each series by using the deciles of the distribution over each sample into a discretely-valued variable, $L_{i t}$, that takes on values from 1 to 10 to refer to each decile. ${ }^{12}$ Thus, when the indicator takes the value of one, this refers to a country-year pair that has among the highest frictions impeding restructuring and liquidation. With this new indicator, the data cover the full time span from 1978 to 2019, totaling 65 business cycles from all 17 countries in our sample.

Using the new variable $L_{i t}$, we can modulate the effect of business credit expansion $\Delta_{5} x_{i t}^{B}$ on the recession with an interaction term. To ease exposition, define $x_{i t}^{B L}=\Delta_{5} x_{i t}^{B} \times L_{i t}$. Using this new variable, we now specify the local projection in Equation 1 as

$$
\Delta_{h} y_{i t(p)+h}=\alpha_{h}+\alpha_{h i}+\beta_{h}^{B L} x_{i t(p)}^{B L}+\beta_{h}^{H} \Delta_{5} x_{i t(p)}^{H}+\beta_{h}^{B} \Delta_{5} x_{i t(p)}^{B}+\gamma_{h} \boldsymbol{w}_{i t(p)}+e_{i t(p)} .
$$

Impulse responses estimated for the 1978-2019 period with OLS for Equation 4 are shown in Figure $7 \mathrm{a}$. The figure shows the recession path as a function of corporate debt 2 standard deviations above the mean in the preceding 5-years modulated by whether bankruptcy procedures are "high-friction" (i.e., $L_{i t}=1$ ), or "low-friction" (i.e., $L_{i t}=10$ ).

This figure makes the point quite strikingly. The harder it is to restructure of liquidate the more protracted and incomplete the recovery. In fact, for the least efficient cases, a preceding corporate debt boom has nearly the same effects on the recovery path as a preceding household debt boom. Institutional frictions can therefore have substantial macroeconomic effects and possibly explain why there is such a difference between household and corporate debt buildups.

However, the institutions of insolvency responds, to some extent, to a country's economic experience as legal systems have evolved alongside society. Hence, a reason for concern is that unobserved factors, independently affecting legal and economic institutions, could create a spurious statistical link between insolvency frictions and recession trajectories. We try to address these concerns using instrumental variable local projections, or LP-IV. Specifically, we instrument the friction indicator using differences in the legal traditions across countries.

In particular, we follow an established literature and distinguish traditions of civil law and common law. The civil law traditions originate in Roman law, but they then morphed into different European varieties under the influence of gradual or drastic change such as the French Revolution. By contrast, the British common law tradition is associated with legal principles of private dispute resolution with less public control (La Porta, Lopez-de-Silanes,

\footnotetext{
${ }^{12}$ The results are virtually unchanged when varying the number of quantiles used to partition the indicators.
} 
Figure 7: Frictions to restructuring and liquidation make the corporate debt overhang worse

(a) OLS estimates modulated by bankruptcy costs

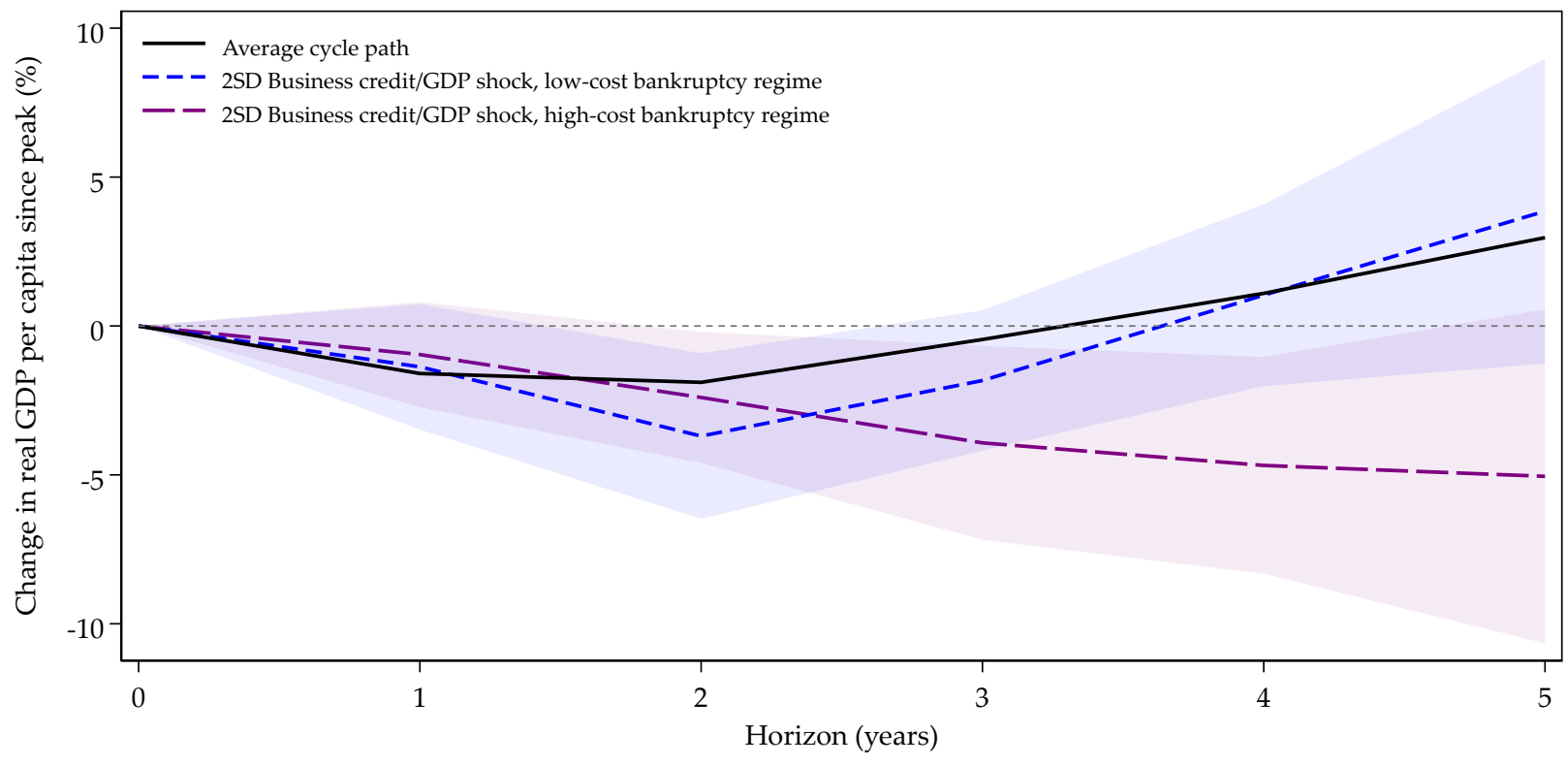

(b) Friction indicators instrumented by the type of legal tradition

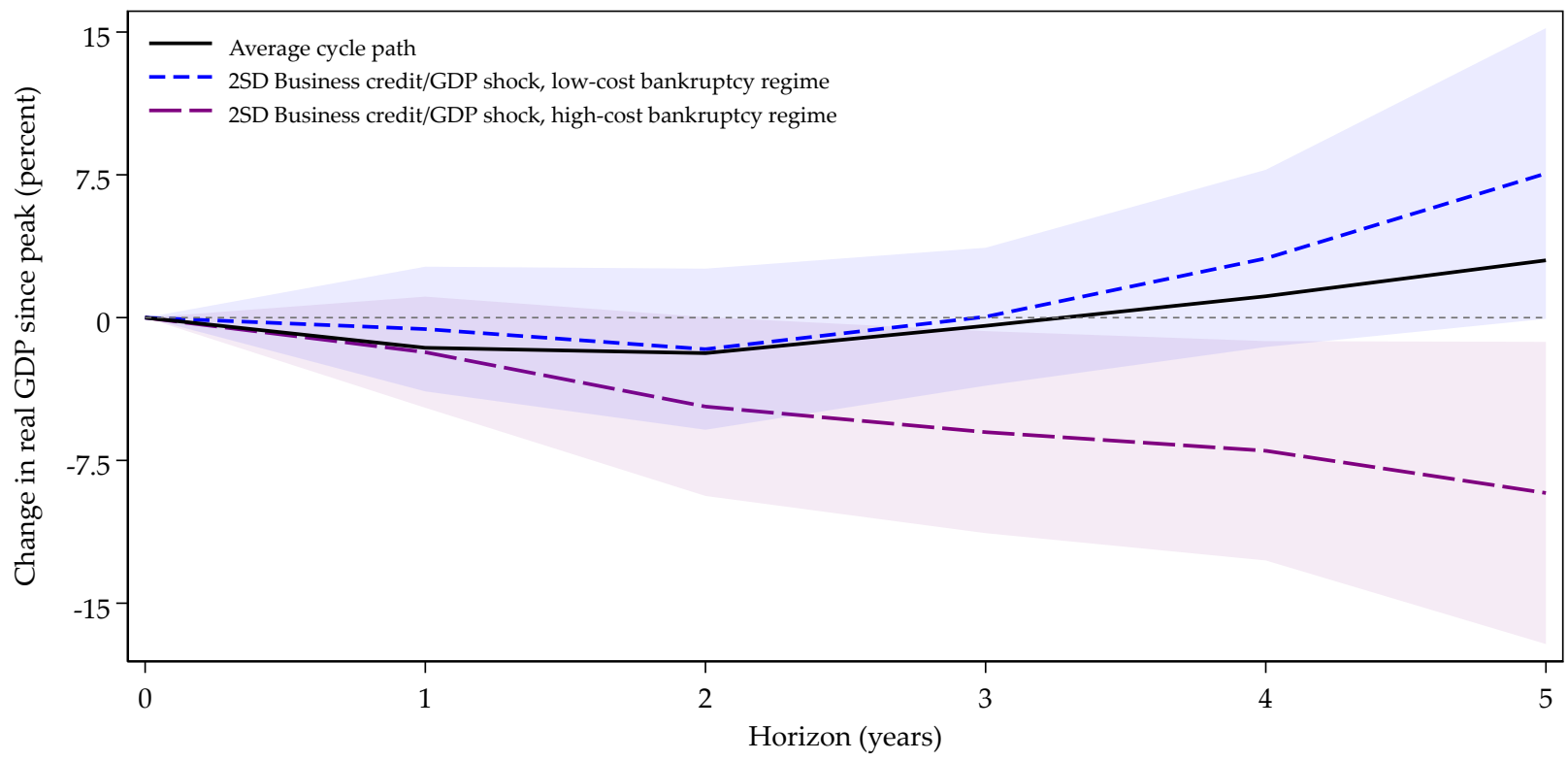

Notes: Both panels show the responses of a 2-SD expansion in business credit/GDP in the five years preceding a recession. The "highfriction" institutions refers to $L_{i t}=1$ whereas the "low-frictoin" institutions refers to $L_{i t}=10$. All estimates are conditional on controls for contemporaneous and two lags of GDP per capita growth and inflation. Panel (a) is based on OLS estimation of Equation 4. Panel (b) instruments friction indicators with a dummy for legal tradition, civil or common law. Standard errors are clustered at the country level. Shaded areas denote the $95 \%$ confidence interval. See text. 
Table 2: Explaining bankruptcy regime quality by legal origin

Dependent variable: Interaction term $x_{i t(p)}^{B L}$

\begin{tabular}{lc}
\hline \hline & $(1)$ \\
\hline Instrument $z_{i t(p)}$ & $-2.55^{* * *}$ \\
& $(0.75)$ \\
Business credit/GDP expansion $\Delta_{5} x_{i t(p)}^{B}$ & $3.26^{* * *}$ \\
& $(0.59)$ \\
Household credit/GDP expansion $\Delta_{5} x_{i t(p)}^{H}$ & -0.14 \\
& $(0.79)$ \\
Macro controls & Yes \\
\hline$F$ statistic & 41.26 \\
$R^{2}$ & 0.54 \\
Cycles & 65 \\
\hline \hline
\end{tabular}

Notes: First stage results for LP-IV estimation. Within-estimator, standard errors clustered on countries in parentheses. ${ }^{* * *} \mathrm{p}<$ o.o1, ${ }^{* *}$ $\mathrm{p}<0.05{ }^{*} \mathrm{p}<0.1$. Credit expansion denotes past 5-year change in credit/GDP ratio. Macro controls include contemporaneous and two lags of GDP per capita growth and inflation.

Shleifer, and Vishny, 1998; Glaeser and Shleifer, 2002). The adoption of either civil or common law dates back to the $17^{\text {th }}$ and $18^{\text {th }}$ centuries, when revolution, colonalisation and Napoleonic conquest laid the foundations of legal principles across Europe and America. In Japan, a variety of German civil law was adopted during extensive reforms under Emperor Meiji at the end of the $19^{\text {th }}$ century (Djankov, McLiesh, and Shleifer, 2007).

Most importantly for us, civil and common law traditions differ in their handling of bankruptcy. Djankov, McLiesh, and Shleifer (2007) and Gamboa-Cavazos and Schneider. (2007) document that civil law systems rely on frequent interlocutory appeals, leading to bankruptcy procedures that are more intricate and costly than those under common law. Based on the coding of legal origins in Djankov, McLiesh, and Shleifer (2007), we instrument the variable $x_{i t}^{B L}$ with the interaction of the business credit buildup variable, $\Delta_{5} x_{i t}^{B}$ and the legal origin dummy, $d_{i t}^{L O}$, that is $z_{i t}=\Delta_{5} x_{i t}^{B} \times d_{i t}^{L O}$ is the instrument for $x_{i t}^{B L}=\Delta_{5} x_{i t}^{B} \times L_{i t}$.

The first stage regression of $x_{i t(p)}^{B L}$ on $z_{i t(p)}$ and controls for our sample of business cycle peaks is shown in Table 2. Our instrument is strong, with an F-statistic above 40, and the sign of the coefficient is significant and consistent with our hypothesis. Common law traditions result in more efficient resolution of corporate financial distress.

The results based on estimating Equation 4 with LP-IV are shown in Figure $7 \mathrm{~b}$. These confirm the findings from Figure $7 a$; although the estimates are slightly less precise the path differences are even starker. As before, frictions impeding restructuring and liquidation aggravate the effects of corporate financial distress to the point of making the recession 
trajectory resemble that from a household debt boom. In contrast, efficient institutions are associated with recession trajectories that resemble normal recession trajectories, even when there is a preceding large buildup of corporate debt. The differences between the "high-friction" and "low-friction" bankruptcy trajectories are statistically significant at the $5 \%$ level.

History contains important lessons. Our IV estimates suggest that deep-rooted legal principles may have a profound impact on how efficiently financial distress from business debt booms is resolved. It makes one wonder if similarly frictionless debt resolution procedures were available to individuals, whether household debt booms would also then be associated with milder recessions.

\section{ConClusion}

Debt overhang can lead to under-investment by firms. Following Myers (1977), a large theoretical literature has explored the idea that investment declines for indebted firms as existing debt holders, not new investors, would be the main beneficiaries from new investment. In practice, the strength of these effects depends on departures from the canonical Modigliani and Miller (1958) theorem. How large these departures are in practice, and how strong the repercussions are from a macro perspective are largely an empirical question. Our results suggest that, at the aggregate level, corporate debt overhang does not play an economically or statistically significant role.

As a first macroeconomic approximation, for the most part we seem to live in a Modigliani-Miller world when it comes to corporate debt overhang in advanced economies. Unlike household credit, business debt can be restructured quickly. Damage from debt overhang is not common. However, the after-effects of business debt booms become more problematic when debt restructuring and liquidation become more costly. In this situation, zombie firms are more likely to emerge as high costs of liquidation increase incentive for banks "extend and pretend" instead of liquidating.

We used institutional proxies for the costs of balance sheet reorganization to delineate different institutional environments that make debt reorganization more or less efficient. In places and times where reorganization and restructuring is inefficient and costly, corporate debt overhang is an important macroeconomic force that has measurably negative effects at business cycle frequency. 


\section{REFERENCES}

Abraham, Facundo, Juan J. Cortina, and Sergio L. Schmukler. 2020. Growth of Global Corporate Debt: Main Facts and Policy Challenges. World Bank Policy Research Working Paper Series 9394.

Admati, Anat R., Peter M. Demarzo, Martin F. Hellwig, and Paul Pfleiderer. 2018. The leverage ratchet effect. Journal of Finance 73(1): 145-198.

Adrian, Tobias, Nina Boyarchenko, and Domenico Giannone. 2019. Vulnerable Growth. American Economic Review 109(4): 1263-1289.

Adrian, Tobias, Federico Grinberg, Nellie Liang, and Sheheryar Malik. 2018. The Term Structure of Growth-at-Risk. IMF Working Paper 18/180.

Agarwal, Sumit, Gene Amromin, Itzhak Ben-David, Souphala Chomsisengphet, Tomasz Piskorski, and Amit Seru. 2016. Policy Intervention in Debt Renegotiation: Evidence from the Home Affordable Modification Program. Journal of Political Economy 125(3): 654-712.

Aivazian, Varouj, and Jeffrey L. Callen. 1980. Corporate leverage and growth the game-theoretic issues. Journal of Financial Economics 8(4): 379-399.

Auclert, Adrien, Will S. Dobbie, and Paul Goldsmith-Pinkham. 2019. Macroeconomic Effects of Debt Relief: Consumer Bankruptcy Protections in the Great Recession. NBER Working Paper 25685.

Bergman, Yaacov, and Jeffrey Callen. 1991. Opportunistic underinvestment in debt renegotiation and capital structure. Journal of Financial Economics 29: 137-171.

Berkovitch, Elazar, and E. Han Kim. 1990. Financial Contracting and Leverage Induced Over- and Under-Investment Incentives. Journal of Finance 45(3): 765-794.

Board of Governors of the Federal Reserve System. 2020. Financial Accounts of the United States Z.1. https://www.federalreserve.gov/releases/z1/.

Bonci, Riccardo, and Massimo Coletta. 2012. Italy's Financial Accounts since 1950. Available at SSRN: http:/ / ssrn.com/abstract=2120474.

Bordo, Michael D., and Joseph G. Haubrich. 2017. Deep Recessions, Fast Recoveries, and Financial Crises: Evidence from the American Record. Economic Inquiry 55(1): 527-541.

Botta, Marco. 2020. Financial crises, debt overhang, and firm growth in transition economies. Applied Economics 52(40): 4333-4350.

Brunnermeier, Markus, and Arvind Krishnamurthy. 2020. The Macroeconomics of Corporate Debt. The Review of Corporate Finance Studies 9(3): 656-665.

Bry, Gerhard, and Charlotte Boschan. 1971. Cyclical Analysis of Time Series: Selected Procedures and Computer Programs. New York: NBER.

Caballero, Ricardo J., Takeo Hoshi, and Anil K. Kashyap. 2008. Zombie Lending and Depressed Restructuring in Japan. American Economic Review 98(5): 1943-77.

Chodorow-Reich, Gabriel. 2014. The Employment Effects of Credit Market Disruptions: Firm-Level Evidence from the 2008-9 Financial Crisis. Quarterly Journal of Economics 129(1): 1-59. 
Covas, Francisco, and Wounter Den Haan. 2011. The Cyclical Behavior of Debt and Equity Finance. American Economic Review 101(2): 877-899.

Dembiermont, Christian, Mathias Drehmann, and Siriporn Muksakunratana. 2013. How much does the private sector really borrow - a new database for total credit to the private non-financial sector. BIS Quarterly Review .

Deutsche Bundesbank. 1983. Revidierte Ergebnisse der gesamtwirtschaftlichen Finanzierungs- und Geldvermögensrechnung für die Jahre 1950-1959. Hauptabteilung Volkswirtschaft, Deutsche Bundesbank, Frankfurt. Technical Report.

Deutsche Bundesbank. 1994. Ergebnisse der gesamtwirtschaftlichen Finanzierungsrechnung für Westdeutschland 1960-1992. Hauptabteilung Volkswirtschaft, Deutsche Bundesbank, Frankfurt. Technical Report.

Diamond, Douglas W., and Zhiguo He. 2014. A Theory of Debt Maturity: The Long and Short of Debt Overhang. Journal of Finance 69(2): 719-762.

Djankov, Simeon, Oliver Hart, Caralee McLiesh, and Andrei Shleifer. 2010. Debt Enforcement around the World. Journal of Political Economy 116(6): 1105-1149.

Djankov, Simeon, Caralee McLiesh, and Andrei Shleifer. 2007. Private Credit in 129 Countries. Journal of Financial Economics 12(2): 77-99.

Fama, Eugene F. 1978. The Effects of a Firm's Investment and Financing Decisions on the Welfare of Its Security Holders. American Economic Review 68(3): 272-284.

Gamboa-Cavazos, Mario, and Frank Schneider. 2007. Bankruptcy as a legal process. Available at SSRN: https:/ / ssrn.com/abstract=979614.

Gertner, Robert, and David Scharfstein. 1991. A Theory of Workouts and the Effects of Reorganization Law. Journal of Finance 46(4): 1189-1222.

Giesecke, Kay, Francis A. Longstaff, Stephen Schaefer, and Ilya A. Strebulaev. 2014. Macroeconomic effects of corporate default crisis: A long-term perspective. Journal of Financial Economics 111(2): 297-310.

Giroud, Xavier, and Holger M. Mueller. 2017. Firm Leverage, Consumer Demand, and Employment Losses during the Great Recession. Quarterly Journal of Economics 132(1): 271-316.

Glaeser, Edward L., and Andrei Shleifer. 2002. Legal Origins. Quarterly Journal of Economics 117(4): 1193-1229.

Hennessey, Christopher A. 2004. Tobin's Q, Debt Overhang, and Investment. Journal of Finance 59(4): 1717-1742.

James, John A., and Richard Sylla. 2006. Debt and Flow of Funds. In Historical Statistics of the United States, edited by Carter, Susan B., Scott Sigmund Gartner, Michael R. Haines, Alan L. Olmstead, Richard Sutch, and Gavin Wright, 3/774-3/776. Cambridge: Cambridge University Press.

Jensen, Michael, and William H. Meckling. 1976. Theory of the firm: Managerial behavior, agency costs and ownership structure. Journal of Financial Economics 3(4): 305-360. 
John, Kose, and David C. Nachman. 1985. Risky Debt, Investment Incentives, and Reputation in a Sequential Equilibrium. Journal of Finance 40(3): 863-878.

Jordà, Òscar. 2005. Estimation and Inference of Impulse Responses by Local Projections. American Economic Review 95(1): 161-182.

Jordà, Òscar, Moritz Schularick, and Alan M. Taylor. 2013. When Credit Bites Back. Journal of Money, Credit and Banking 45(2): 3-28.

Jordà, Òscar, Moritz Schularick, and Alan M. Taylor. 2017. Macrofinancial History and the New Business Cycle Facts. In NBER Macroeconomics Annual 2016, edited by Eichenbaum, Martin, and Jonathan A. Parker. Chicago: University of Chicago Press.

Jordà, Òscar, Moritz Schularick, and Alan M. Taylor. 2020. Disasters Everywhere: The Costs of Business Cycles Reconsidered. NBER Working Paper 26962.

Kalemli-Özcan, Sebnem, Luc Laeven, and David Moreno. 2020. Debt overhang, rollover risk and corporate investment: Evidence from the European crisis. ECB Working Paper 2241.

Kuchler, Andreas. 2020. Leverage, Investment, and Recovery from a Financial Crisis: The Role of Debt Overhang. Studies in Economics and Finance 37(1): 143-159.

La Porta, Rafael, Florencio Lopez-De-Silanes, and Andrei Shleifer. 2008. The Economic Consequences of Legal Origins. Journal of Economic Literature 46(2): 285-332.

La Porta, Rafael, Florencio Lopez-de-Silanes, Andrei Shleifer, and Robert W. Vishny. 1997. The Legal Determinants of External Finance. Journal of Finance 52(3): 1131-1150.

La Porta, Rafael, Florencio Lopez-de-Silanes, Andrei Shleifer, and Robert W. Vishny. 1998. Law and Finance. Journal of Political Economy 106(6): 1113-1155.

Lamont, Owen. 1995. Corporate debt overhang and macroeconomic expectations. American Economic Review 85(5): 1106-1117.

Lang, Larry, Eli Ofek, and Rene M. Stulz. 1996. Leverage, Investment, and Firm Growth. Journal of Financial Economics 4O(1): 3-29.

Linnemann, Ludger, and Roland Winkler. 2016. Estimating nonlinear effects of fiscal policy using quantile regression methods. Oxford Economic Papers 68(4): 1120-1145.

Loria, Francesca, Christian Matthes, and Donghai Zhang. 2019. Assessing macroeconomic tail risk. Federal Reserve Board Finance and Economics Discussion Paper 2019-026.

McGowan, Müge Adalet, Dan Andrews, Valentine Millot, and Thorsten Beck. 2018. The walking dead? Zombie firms and productivity performance in OECD countries. Economic Policy 33(96): $685-736$.

Mian, Atif, and Amir Sufi. 2010. Household Leverage and the Recession of 2007-09. IMF Economic Review 58(1): 74-117.

Mian, Atif, Amir Sufi, and Emil Verner. 2017. Household Debt and Business Cycles Worldwide. Quarterly Journal of Economics 132(4): 1755-1817. 
Mitman, Kurt. 2016. Macroeconomic Effects of Bankruptcy and Foreclosure Policies. American Economic Review 106(8): 2219-2250.

Modigliani, Franco, and Merton H. Miller. 1958. The Cost of Capital, Corporation Finance and the Theory of Investment. American Economic Review 48(3): 261-297.

Müller, Karsten. 2018. Credit Markets around the World, 1910-2014. Available at SSRN: https:/ / ssrn.com/abstract=3259636.

Myers, Stewart C. 1977. Determinants of corporate borrowing. Journal of Financial Economics 5(2): 147-175.

Myers, Stewart C., and Nicholas S. Majluf. 1984. Corporate financing and investment decisions when firms have information that investors do not have. Journal of Financial Economics 13(2): 187-221.

Niemi-Kiesiläinen, Johanna. 1997. Changing Directions in Consumer Bankruptcy Law and Practice in Europe and USA. Journal of Consumer Policy 20: 133-142.

Occhino, Filippo, and Andrea Pescatori. 2015. Debt overhang in a business cycle model. European Economic Review 73(C): 58-84.

Office for National Statistics. 2016. Pre-ESA95 financial accounts and balance sheets. Data retrieved from https://www.ons.gov.uk/economy/nationalaccounts/uksectoraccounts.

Philippon, Thomas. 2010. Debt Overhang and Recapitalization in Closed and Open Economies. IMF Economic Review 58(1): 157-178.

Popov, Alexander, Francesca Barbiero, and Marcin Wolski. 2018. Debt overhang and investment efficiency. ECB Working Paper 2213.

Reinhart, Carmen M., and Kenneth S. Rogoff. 2014. Recovery from Financial Crises: Evidence from 100 Episodes. American Economic Review 104(5): 50-55.

Roe, Alan. 1971. The financial interdependence of the UK economy 1957-66. London: Chapman \& Hall.

Stolbov, Mikhail, and Maria Shchepeleva. 2020. Macrofinancial linkages in Europe: Evidence from quantile local projections. International Journal of Finance \& Economics forthcoming. 


\section{ONLINE APPENDIX}

\section{A. Business CYCLE PEAKS}

As described in the text, we date business cycle peaks using the algorithm of Bry and Boschan (1971). Moreover, we characterize the ensuing recession to be "financial" when the peak falls into a \pm 2 -year window around a financial crisis dated by Jordà, Schularick, and Taylor (2017). Table A.1 shows business cycle peaks followed by normal recession and not falling into any war episode. Table A.2 shows business cycle peaks followed by normal recession and not falling into any war episode. Both types of peaks are also visualized in Figure A.1.

Table A.1: List of business cycle peaks followed by normal recessions

\begin{aligned} & \hline Australia $1956,1961,1973,1976,1981,2008 \\ &$ Belgium $1957,1974,1980,1992,2011 \\ &$ Canada $1891,1894,1903,1928,1953,1956,1981,1989,2007 \\ &$ Denmark $1880,1887,1931,1962,1973,1979,1992,2011 \\ &$ Finland $1957,1975,2008,2011 \\ &$ France $1905,1907,1926,1933,1974,1992,2011 \\ &$ Germany $1898,1905,1908,1966,1974,1980,1992,2001 \\ &$ Ireland $1955,1974,1982,2010 \\ &$ Italy $1974,2002,2011 \\ &$ Japan $1973,2001,2007 \\ &$ Netherlands $1957,1974,1980,2001,2011 \\ &$ Norway $1876,1881,1885,1893,1902,1957,1981,2007,2012 \\ &$ Portugal $1973,1982,1992,2002,2010 \\ &$ Spain $1927,1952,1958,1980,1992 \\ &$ Sweden $1876,1881,1883,1885,1888,1890,1899,1901,1904,1924,1980,2011 \\ &$ Switzerland $1875,1880,1886,1890,1893,1899,1902,1906,1933,1951,1957,1974,1981,1994,2001,2011 \\ &$ UK $1896,1899,1902,1907,1925,1929,1951,1957,1979 \\ &$ USA $1926,1953,1957,1969,1973,1979,1981,1990,2000 \\ &$\hline\end{aligned}

Table A.2: List of business cycle peaks followed by financial recessions

\begin{aligned} & \hline Australia 1989 \\ & Belgium 2007 \\ & Canada 1907 \\ & Denmark $1883,1987,2007 \\ &$ Finland 1989 \\ & France 1929,2007 \\ & Germany 1890,2008 \\ & Ireland 2007 \\ & Italy 1992,2007 \\ & Japan 1997 \\ & Netherlands 2008 \\ & Norway $1897,1930,1987 \\ &$ Portugal 2008 \\ & Spain $1925,1929,2007 \\ &$ Sweden $1879,1907,1930,1990,2007 \\ &$ Switzerland $1929,1990,2008 \\ &$ UK $1889,1973,1990,2007 \\ &$ USA 1929,2007 \\ & \hline\end{aligned}


Figure A.1: Business cycle peaks followed by financial and normal recessions
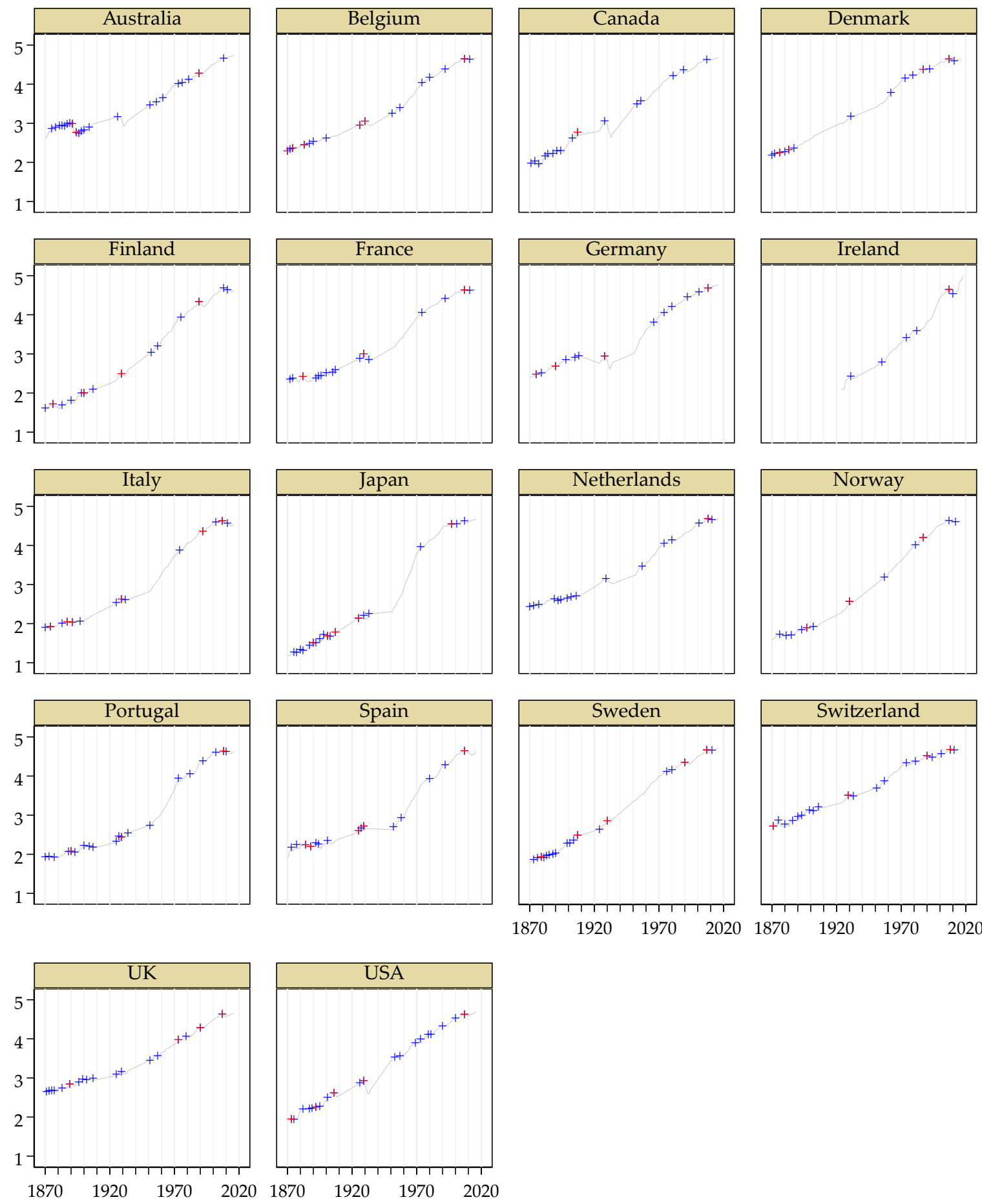

\section{Log real GDP}

$+\quad$ Business cycle peak

$+\quad$ Business cycle peak followed by financial recession 


\section{B. MACROECONOMIC ENVIRONMENT}

We show regression tables for the plots in the main text and additional impulse responses (without tables), all conditional on the usual set of controls.

Table A.3: Change in log real consumption

\begin{tabular}{|c|c|c|c|c|c|}
\hline & $\begin{array}{c}(1) \\
h=1\end{array}$ & $\begin{array}{c}(2) \\
h=2\end{array}$ & $\begin{array}{c}(3) \\
h=3\end{array}$ & $\begin{array}{c}(4) \\
h=4\end{array}$ & $\begin{array}{c}(5) \\
h=5\end{array}$ \\
\hline Average cycle & $\begin{array}{l}-0.01 \\
(0.19)\end{array}$ & $\begin{array}{c}1.53^{* * *} \\
(0.15)\end{array}$ & $\begin{array}{c}2.78^{* * *} \\
(0.18)\end{array}$ & $\begin{array}{c}5.26^{* * *} \\
(0.29)\end{array}$ & $\begin{array}{c}7 \cdot 49^{* * *} \\
(0.30)\end{array}$ \\
\hline Business credit/GDP expansion $\Delta_{5} x_{i t(p)}^{B}$ & $\begin{array}{l}-2.42 \\
(1.97)\end{array}$ & $\begin{array}{c}0.95 \\
(1.97)\end{array}$ & $\begin{array}{l}-2.36 \\
(3.25)\end{array}$ & $\begin{array}{l}-3.74 \\
(3.85)\end{array}$ & $\begin{array}{l}-4.69 \\
(5.29)\end{array}$ \\
\hline Household credit/GDP expansion $\Delta_{5} x_{i t(p)}^{H}$ & $\begin{array}{l}-1.02 \\
(3.98)\end{array}$ & $\begin{array}{c}-13.01^{* *} \\
(5.42)\end{array}$ & $\begin{array}{c}-21.44^{* * *} \\
(5.08)\end{array}$ & $\begin{array}{c}-34 \cdot 39^{* * *} \\
(7 \cdot 70)\end{array}$ & $\begin{array}{c}-41.62^{* * *} \\
(7 \cdot 36)\end{array}$ \\
\hline Macro controls & Yes & Yes & Yes & Yes & Yes \\
\hline$\beta_{h}^{B}=\beta_{h}^{H}(\mathrm{p}$-value $)$ & 0.765 & 0.032 & 0.004 & 0.004 & 0.000 \\
\hline$R^{2}$ & 0.23 & 0.30 & 0.42 & 0.39 & 0.37 \\
\hline Cycles & 150 & 150 & 150 & 150 & 149 \\
\hline
\end{tabular}

Within-estimator, standard errors clustered on countries in parentheses.

*** $\mathrm{p}<0.01,{ }^{* *} \mathrm{p}<0.05,{ }^{*} \mathrm{p}<0.1$. 
Table A.4: Change in log real investment

\begin{tabular}{|c|c|c|c|c|c|}
\hline & $\begin{array}{c}(1) \\
h=1\end{array}$ & $\begin{array}{c}(2) \\
h=2\end{array}$ & $\begin{array}{c}(3) \\
h=3\end{array}$ & $\begin{array}{c}(4) \\
h=4\end{array}$ & $\begin{array}{c}(5) \\
h=5\end{array}$ \\
\hline Average cycle & $\begin{array}{c}-4.15^{* * *} \\
(0.36)\end{array}$ & $\begin{array}{c}-6.69^{* * *} \\
(0.71)\end{array}$ & $\begin{array}{c}-8.49^{* * *} \\
(1.11)\end{array}$ & $\begin{array}{c}-7.11^{* * *} \\
(1.28)\end{array}$ & $\begin{array}{l}-3.07^{*} \\
(1.51)\end{array}$ \\
\hline Business credit/GDP expansion $\Delta_{5} x_{i t(p)}^{B}$ & $\begin{array}{c}4.07 \\
(5 \cdot 36)\end{array}$ & $\begin{array}{l}5 \cdot 72 \\
(7.88)\end{array}$ & $\begin{array}{c}7.4^{2} \\
(11.52)\end{array}$ & $\begin{array}{c}7.91 \\
(14.05)\end{array}$ & $\begin{array}{c}11.10 \\
(15.75)\end{array}$ \\
\hline Household credit/GDP expansion $\Delta_{5} x_{i t(p)}^{H}$ & $\begin{array}{l}-18.36 \\
(13.13)\end{array}$ & $\begin{array}{c}-76.52^{* *} \\
(26.83)\end{array}$ & $\begin{array}{c}-123.83^{* * *} \\
(38.64)\end{array}$ & $\begin{array}{c}-142.23^{* * *} \\
(34.67)\end{array}$ & $\begin{array}{c}-128.06^{* * *} \\
(31.40)\end{array}$ \\
\hline Macro controls & Yes & Yes & Yes & Yes & Yes \\
\hline$\beta_{h}^{B}=\beta_{h}^{H}(\mathrm{p}$-value $)$ & 0.127 & 0.011 & 0.007 & 0.002 & 0.002 \\
\hline$R^{2}$ & 0.27 & 0.38 & 0.36 & 0.43 & 0.46 \\
\hline Cycles & 150 & 150 & 150 & 150 & 149 \\
\hline
\end{tabular}

Within-estimator, standard errors clustered on countries in parentheses.

${ }^{* * *} \mathrm{p}<0.01,{ }^{* *} \mathrm{p}<0.05,{ }^{*} \mathrm{p}<0.1$.

Table A.5: Change in unemployment rate

\begin{tabular}{|c|c|c|c|c|c|}
\hline & $\begin{array}{c}(1) \\
h=1\end{array}$ & $\begin{array}{c}(2) \\
h=2\end{array}$ & $\begin{array}{c}(3) \\
h=3\end{array}$ & $\begin{array}{c}(4) \\
h=4\end{array}$ & $\begin{array}{c}(5) \\
h=5\end{array}$ \\
\hline Average cycle & $\begin{array}{c}1.21^{* * *} \\
(0.28)\end{array}$ & $\begin{array}{c}2.26^{* * *} \\
(0.42)\end{array}$ & $\begin{array}{c}2.89^{* * *} \\
(0.53)\end{array}$ & $\begin{array}{c}2.87^{* * *} \\
(0.72)\end{array}$ & $\begin{array}{c}2.94^{* * *} \\
(0.92)\end{array}$ \\
\hline Business credit/GDP expansion $\Delta_{5} x_{i t(p)}^{B}$ & $\begin{array}{c}0.65 \\
(1.05)\end{array}$ & $\begin{array}{c}0.50 \\
(2.70)\end{array}$ & $\begin{array}{c}0.62 \\
(3 \cdot 57)\end{array}$ & $\begin{array}{c}0.69 \\
(4 \cdot 38)\end{array}$ & $\begin{array}{l}-0.13 \\
(4.51)\end{array}$ \\
\hline Household credit/GDP expansion $\Delta_{5} x_{i t(p)}^{H}$ & $\begin{array}{c}0.32 \\
(3.13)\end{array}$ & $\begin{array}{c}6.67 \\
(6.81)\end{array}$ & $\begin{array}{l}13.24 \\
(8.27)\end{array}$ & $\begin{array}{c}16.19^{*} \\
(8.64)\end{array}$ & $\begin{array}{l}14.57 \\
(8.76)\end{array}$ \\
\hline Macro controls & Yes & Yes & Yes & Yes & Yes \\
\hline$\beta_{h}^{B}=\beta_{h}^{H}(\mathrm{p}$-value $)$ & 0.926 & 0.414 & 0.203 & 0.167 & 0.165 \\
\hline$R^{2}$ & 0.41 & 0.24 & 0.35 & 0.35 & 0.34 \\
\hline Cycles & 112 & 113 & 113 & 113 & 112 \\
\hline
\end{tabular}

Within-estimator, standard errors clustered on countries in parentheses.

${ }^{* * *} \mathrm{p}<0.01,{ }^{* *} \mathrm{p}<0.05,{ }^{*} \mathrm{p}<0.1$. 
Table A.6: Change in log real household credit

\begin{tabular}{|c|c|c|c|c|c|}
\hline & $\begin{array}{c}(1) \\
h=1\end{array}$ & $\begin{array}{c}(2) \\
h=2\end{array}$ & $\begin{array}{c}(3) \\
h=3\end{array}$ & $\begin{array}{c}(4) \\
h=4\end{array}$ & $\begin{array}{c}(5) \\
h=5\end{array}$ \\
\hline Average cycle & $\begin{array}{c}3 \cdot 47^{* * *} \\
(0.23)\end{array}$ & $\begin{array}{c}8.21^{* * *} \\
(0.43)\end{array}$ & $\begin{array}{c}13.73^{* * *} \\
(0.53)\end{array}$ & $\begin{array}{c}18.47^{* * *} \\
(0.72)\end{array}$ & $\begin{array}{c}22.24^{* * *} \\
(1.02)\end{array}$ \\
\hline Business credit/GDP expansion $\Delta_{5} x_{i t(p)}^{B}$ & $\begin{array}{c}-14.97^{* * *} \\
(4.13)\end{array}$ & $\begin{array}{c}-34.65^{* * *} \\
(10.52)\end{array}$ & $\begin{array}{c}-46.26^{* * *} \\
(12.94)\end{array}$ & $\begin{array}{c}-43.16^{* *} \\
(19.47)\end{array}$ & $\begin{array}{l}-42.63^{* *} \\
(19.40)\end{array}$ \\
\hline Household credit/GDP expansion $\Delta_{5} x_{i t(p)}^{H}$ & $\begin{array}{l}-15.39 \\
(15.82)\end{array}$ & $\begin{array}{l}-33.95 \\
(34.28)\end{array}$ & $\begin{array}{l}-84.19^{*} \\
(40.83)\end{array}$ & $\begin{array}{c}-136.08^{* *} \\
(48.83)\end{array}$ & $\begin{array}{c}-163.71^{* * *} \\
(43.57)\end{array}$ \\
\hline Macro controls & Yes & Yes & Yes & Yes & Yes \\
\hline$\beta_{h}^{B}=\beta_{h}^{H}(\mathrm{p}$-value $)$ & 0.982 & 0.987 & 0.453 & 0.137 & 0.039 \\
\hline$R^{2}$ & 0.28 & 0.30 & 0.38 & 0.33 & 0.41 \\
\hline Cycles & 149 & 149 & 149 & 149 & 146 \\
\hline
\end{tabular}

Within-estimator, standard errors clustered on countries in parentheses.

${ }^{* * *} \mathrm{p}<0.01,{ }^{* *} \mathrm{p}<0.05,{ }^{*} \mathrm{p}<0.1$.

Table A.7: Change in log real business credit

\begin{tabular}{|c|c|c|c|c|c|}
\hline & $\begin{array}{c}(1) \\
h=1\end{array}$ & $\begin{array}{c}(2) \\
h=2\end{array}$ & $\begin{array}{c}(3) \\
h=3\end{array}$ & $\begin{array}{c}(4) \\
h=4\end{array}$ & $\begin{array}{c}(5) \\
h=5\end{array}$ \\
\hline Average cycle & $\begin{array}{c}2.81^{* * *} \\
(0.30)\end{array}$ & $\begin{array}{c}5.03^{* * *} \\
(0.50)\end{array}$ & $\begin{array}{c}7.25^{* * *} \\
(0.55)\end{array}$ & $\begin{array}{c}9.83^{* * *} \\
(0.75)\end{array}$ & $\begin{array}{c}14.27^{* * *} \\
(1.11)\end{array}$ \\
\hline Business credit/GDP expansion $\Delta_{5} x_{i t(p)}^{B}$ & $\begin{array}{c}-15.63^{* * *} \\
(5.12)\end{array}$ & $\begin{array}{c}-23.92^{* *} \\
(11.31)\end{array}$ & $\begin{array}{l}-27.45 \\
(18.10)\end{array}$ & $\begin{array}{l}-40.04^{*} \\
(22.32)\end{array}$ & $\begin{array}{l}-53.63^{*} \\
(30.46)\end{array}$ \\
\hline Household credit/GDP expansion $\Delta_{5} x_{i t(p)}^{H}$ & $\begin{array}{c}5.71 \\
(10.53)\end{array}$ & $\begin{array}{l}-23.45 \\
(19.27)\end{array}$ & $\begin{array}{c}-76.24^{* *} \\
(27.34)\end{array}$ & $\begin{array}{c}-117.96^{* * *} \\
(36.41)\end{array}$ & $\begin{array}{r}-191.16^{* *} \\
(43.57)\end{array}$ \\
\hline Macro controls & Yes & Yes & Yes & Yes & Yes \\
\hline$\beta_{h}^{B}=\beta_{h}^{H}(\mathrm{p}$-value $)$ & 0.108 & 0.985 & 0.190 & 0.112 & 0.031 \\
\hline$R^{2}$ & 0.40 & 0.35 & 0.29 & 0.30 & 0.32 \\
\hline Cycles & 149 & 149 & 149 & 149 & 148 \\
\hline
\end{tabular}

Within-estimator, standard errors clustered on countries in parentheses.

${ }^{* * *} \mathrm{p}<0.01,{ }^{* *} \mathrm{p}<0.05,{ }^{*} \mathrm{p}<0.1$. 
Table A.8: Change in $\log C P I$

\begin{tabular}{|c|c|c|c|c|c|}
\hline & $\begin{array}{c}(1) \\
h=1\end{array}$ & $\begin{array}{c}(2) \\
h=2\end{array}$ & $\begin{array}{c}(3) \\
h=3\end{array}$ & $\begin{array}{c}(4) \\
h=4\end{array}$ & $\begin{array}{c}(5) \\
h=5\end{array}$ \\
\hline Average cycle & $\begin{array}{c}3.00^{* * *} \\
(0.11)\end{array}$ & $\begin{array}{c}4.69^{* * *} \\
(0.22)\end{array}$ & $\begin{array}{c}5.90^{* * *} \\
(0.32)\end{array}$ & $\begin{array}{c}7 \cdot 75^{* * *} \\
(0.40)\end{array}$ & $\begin{array}{c}9.30^{* * *} \\
(0.51)\end{array}$ \\
\hline Business credit/GDP expansion $\Delta_{5} x_{i t(p)}^{B}$ & $\begin{array}{l}-0.63 \\
(2.26)\end{array}$ & $\begin{array}{l}-1.28 \\
(4.63)\end{array}$ & $\begin{array}{c}0.27 \\
(6.54)\end{array}$ & $\begin{array}{c}2.58 \\
(7.68)\end{array}$ & $\begin{array}{c}2.27 \\
(8.55)\end{array}$ \\
\hline Household credit/GDP expansion $\Delta_{5} x_{i t(p)}^{H}$ & $\begin{array}{c}0.55 \\
(4.55)\end{array}$ & $\begin{array}{c}3.89 \\
(11.30)\end{array}$ & $\begin{array}{c}2.80 \\
(14.25)\end{array}$ & $\begin{array}{c}-8.27 \\
(17.01)\end{array}$ & $\begin{array}{l}-20.87 \\
(18.90)\end{array}$ \\
\hline Macro controls & Yes & Yes & Yes & Yes & Yes \\
\hline$\beta_{h}^{B}=\beta_{h}^{H}(\mathrm{p}$-value $)$ & 0.789 & 0.621 & 0.854 & 0.542 & 0.257 \\
\hline Cycles & 150 & 150 & 150 & 150 & 150 \\
\hline
\end{tabular}

Within-estimator, standard errors clustered on countries in parentheses.

${ }^{* * *} \mathrm{p}<0.01,{ }^{* *} \mathrm{p}<0.05{ }^{*} \mathrm{p}<0.1$.

Figure A.2: Conditional effect of $2 S D$ debt expansion on real imports

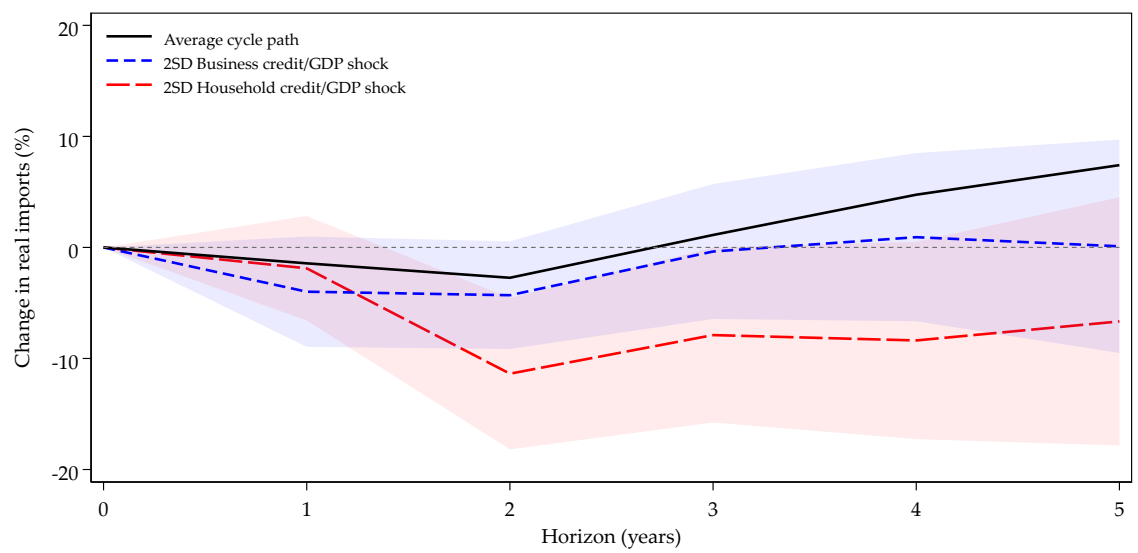

Notes: The figure shows the effects of a two-SD credit expansion in the five years preceding the recession for household credit booms (lhs) and business credit booms (rhs). The estimations rely on all business cycles in 17 advanced economies since WW2. 
Figure A.3: Conditional effect of 2 SD debt expansion real residential investment

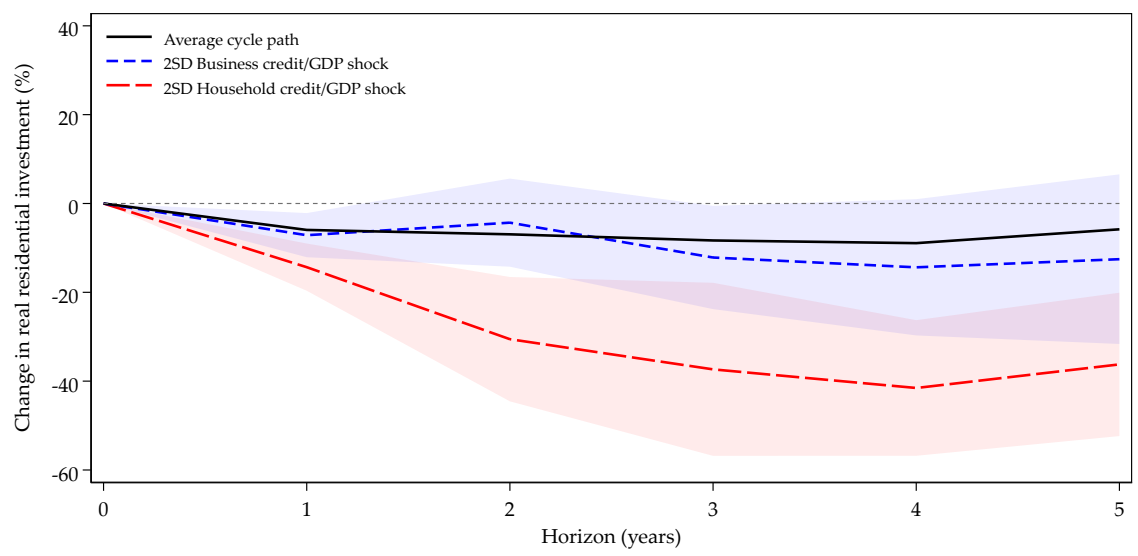

Notes: The figure shows the effects of a two-SD credit expansion in the five years preceding the recession for household credit booms (lhs) and business credit booms (rhs). The estimations rely on all business cycles in 17 advanced economies since WW2.

Figure A.4: Conditional effect of 2 SD debt expansion on short-term real rates

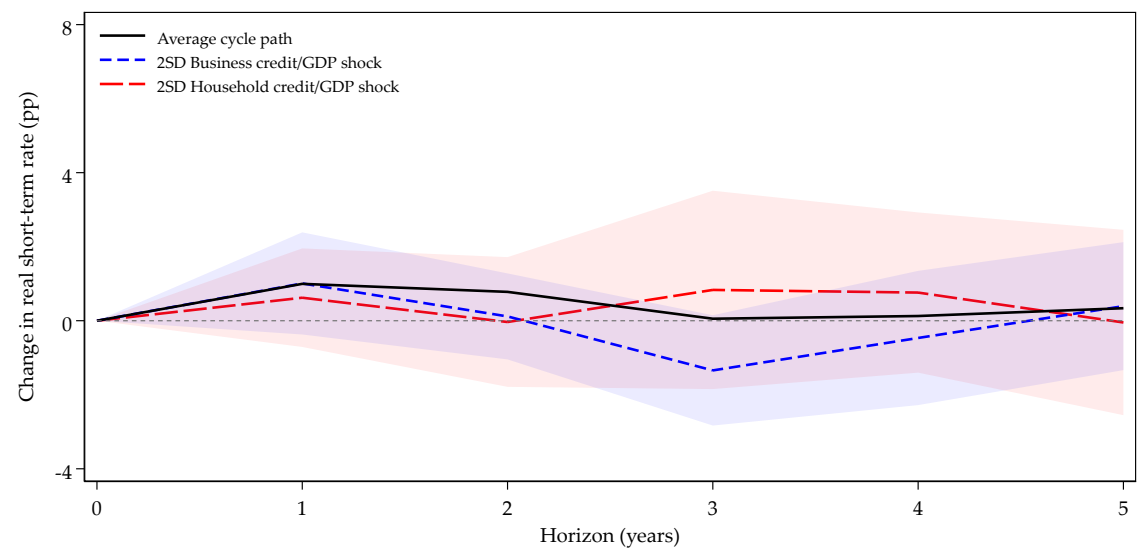

Notes: The figure shows the effects of a two-SD credit expansion in the five years preceding the recession for household credit booms (lhs) and business credit booms (rhs). The estimations rely on all business cycles in 17 advanced economies since WW2. 
Figure A.5: Conditional effects of 2-SD-expansion on nominal short-term interest

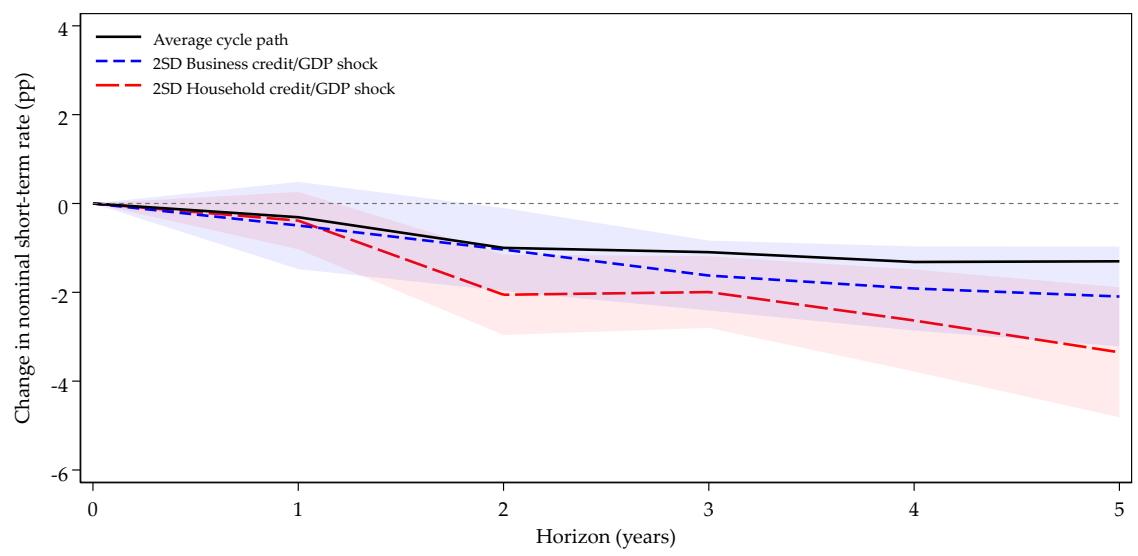

Notes: The figure shows the effects of a two-SD credit expansion in the five years preceding the recession for household credit booms (lhs) and business credit booms (rhs). The estimations rely on all business cycles in 17 advanced economies since WW2.

Figure A.6: Conditional effects of 2-SD-expansion on nominal long-term interest

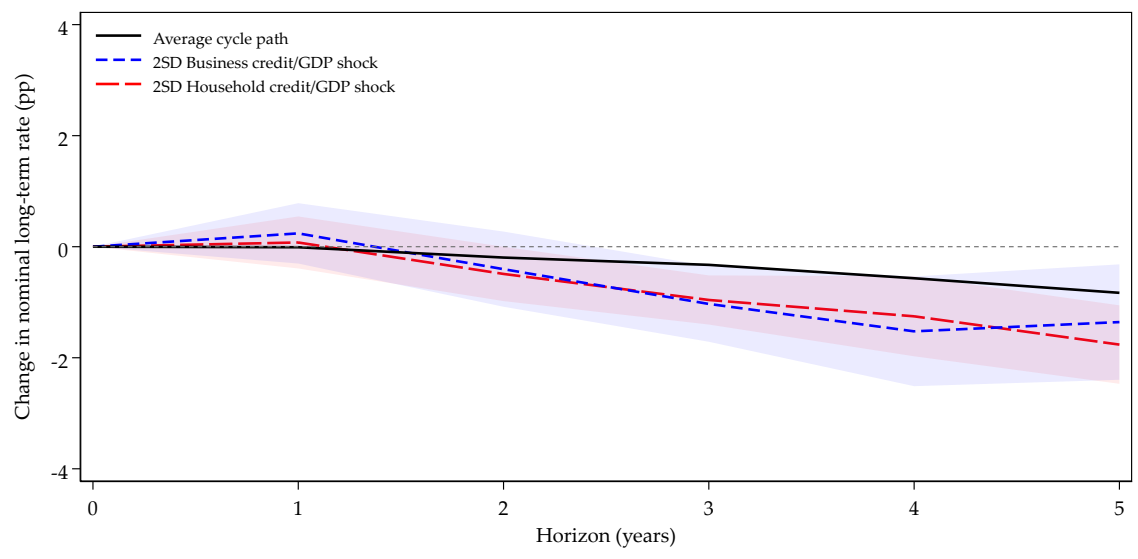

Notes: The figure shows the effects of a two-SD credit expansion in the five years preceding the recession for household credit booms (lhs) and business credit booms (rhs). The estimations rely on all business cycles in 17 advanced economies since WW2. 


\section{Robustness}

We test different specifications for our main model and expose it to a battery of robustness checks. Results are documented below. Across all variants, we find no evidence of significant and quantitatively relevant debt overhang effects.

We introduce linear and quadratic time trends (Table A.9), exclude all recessions from 2007 onwards (Table A.10) and test alternative measures of debt overhang (Table A.11, Table A.12, Table A.13). We also report unconditional estimates in ??. Finally, we test whether the effects of business credit expansions show up only at particularly high or low levels of business debt levels. We introduce an interaction term of 5-year changes in business credit/GDP with the level of business credit/GDP at peak and condition on the usual set of macro controls, country fixed effects and a linear and quadratic time trend. Figure A.7 plots the effects of a 2SD business credit expansion when the business credit/GDP level hovers 2SD above country-specific historical average.

Table A.9: Introducing linear and quadratic time trends

\begin{tabular}{|c|c|c|c|c|c|}
\hline & $\begin{array}{c}(1) \\
h=1\end{array}$ & $\begin{array}{c}(2) \\
h=2\end{array}$ & $\begin{array}{c}(3) \\
h=3\end{array}$ & $\begin{array}{c}(4) \\
h=4\end{array}$ & $\begin{array}{c}(5) \\
h=5\end{array}$ \\
\hline Average cycle & $\begin{array}{c}-1.59^{* * *} \\
(0.13)\end{array}$ & $\begin{array}{c}-0.78^{* * *} \\
(0.22)\end{array}$ & $\begin{array}{l}0.66^{*} \\
(0.33)\end{array}$ & $\begin{array}{c}1.93^{* * *} \\
(0.38)\end{array}$ & $\begin{array}{c}3.63^{* * *} \\
(0.50)\end{array}$ \\
\hline Business credit/GDP expansion $\Delta_{5} x_{i t(p)}^{B}$ & $\begin{array}{c}0.55 \\
(1.17)\end{array}$ & $\begin{array}{c}2.10 \\
(2.01)\end{array}$ & $\begin{array}{l}-1.02 \\
(2.54)\end{array}$ & $\begin{array}{l}-0.86 \\
(4 \cdot 57)\end{array}$ & $\begin{array}{l}1.35 \\
(4.98)\end{array}$ \\
\hline Household credit/GDP expansion $\Delta_{5} x_{i t(p)}^{H}$ & $\begin{array}{l}-6.38 \\
(4.26)\end{array}$ & $\begin{array}{c}-16.75^{* *} \\
(6.73)\end{array}$ & $\begin{array}{c}-25.29^{* * *} \\
(7.82)\end{array}$ & $\begin{array}{c}-34.41^{* * *} \\
(11.77)\end{array}$ & $\begin{array}{c}-33.49^{* *} \\
(12.43)\end{array}$ \\
\hline Macro controls & Yes & Yes & Yes & Yes & Yes \\
\hline Time trends & Yes & Yes & Yes & Yes & Yes \\
\hline$\beta_{h}^{B}=\beta_{h}^{H}(\mathrm{p}$-value $)$ & 0.163 & 0.021 & 0.010 & 0.030 & 0.027 \\
\hline$R^{2}$ & 0.17 & 0.38 & 0.43 & 0.47 & 0.50 \\
\hline Cycles & 150 & 150 & 150 & 150 & 149 \\
\hline
\end{tabular}

Within-estimator, standard errors clustered on countries in parentheses.

${ }^{* * *} \mathrm{p}<0.01,{ }^{* *} \mathrm{p}<0.05,^{*} \mathrm{p}<0.1$. 
Table A.10: Omitting recessions post 2006

\begin{tabular}{|c|c|c|c|c|c|}
\hline & $\begin{array}{c}(1) \\
h=1\end{array}$ & $\begin{array}{c}(2) \\
h=2\end{array}$ & $\begin{array}{c}(3) \\
h=3\end{array}$ & $\begin{array}{c}(4) \\
h=4\end{array}$ & $\begin{array}{c}(5) \\
h=5\end{array}$ \\
\hline Average cycle & $\begin{array}{c}-1.59^{* * *} \\
(0.10)\end{array}$ & $\begin{array}{c}-0.47^{* * *} \\
(0.14)\end{array}$ & $\begin{array}{c}1.12^{* * *} \\
(0.19)\end{array}$ & $\begin{array}{c}2.82^{* * *} \\
(0.31)\end{array}$ & $\begin{array}{c}4.91^{* * *} \\
(0.42)\end{array}$ \\
\hline Business credit/GDP expansion $\Delta_{5} x_{i t(p)}^{B}$ & $\begin{array}{l}-0.42 \\
(1.17)\end{array}$ & $\begin{array}{c}1.61 \\
(1.96)\end{array}$ & $\begin{array}{l}-2.73 \\
(3.28)\end{array}$ & $\begin{array}{l}-2.75 \\
(4.52)\end{array}$ & $\begin{array}{l}-0.95 \\
(5.25)\end{array}$ \\
\hline Household credit/GDP expansion $\Delta_{5} x_{i t(p)}^{H}$ & $\begin{array}{l}-4.56 \\
(4.19)\end{array}$ & $\begin{array}{c}-12.49^{*} \\
(6.57)\end{array}$ & $\begin{array}{c}-28.38^{* *} \\
(10.34)\end{array}$ & $\begin{array}{c}-40.15^{* *} \\
(14.36)\end{array}$ & $\begin{array}{c}-40.00^{* *} \\
(14.27)\end{array}$ \\
\hline Macro controls & Yes & Yes & Yes & Yes & Yes \\
\hline$\beta_{h}^{B}=\beta_{h}^{H}(\mathrm{p}$-value $)$ & 0.364 & 0.055 & 0.010 & 0.015 & 0.011 \\
\hline$R^{2}$ & 0.21 & 0.32 & 0.39 & 0.42 & 0.41 \\
\hline Cycles & 121 & 121 & 121 & 121 & 121 \\
\hline
\end{tabular}

Within-estimator, standard errors clustered on countries in parentheses.

*** $\mathrm{p}<0.01,{ }^{* *} \mathrm{p}<0.05,^{*} \mathrm{p}<0.1$.

Table A.11: Expansion measured by 3-year change in credit/GDP

\begin{tabular}{lccccc}
\hline \hline & $(1)$ & $(2)$ & $(3)$ & $(4)$ & $(5)$ \\
& $h=1$ & $h=2$ & $h=3$ & $h=4$ & $h=5$ \\
\hline Average cycle & $-1.57^{* * *}$ & -0.40 & $1.54^{* * *}$ & $3.49^{* * *}$ & $6.24^{* * *}$ \\
& $(0.18)$ & $(0.34)$ & $(0.53)$ & $(0.74)$ & $(0.77)$ \\
Business credit/GDP expansion $\Delta_{3} x_{i t(p)}^{B}$ & -0.85 & 1.74 & -2.21 & -4.83 & -10.48 \\
& $(2.55)$ & $(6.98)$ & $(8.26)$ & $(11.05)$ & $(10.82)$ \\
Household credit/GDP expansion $\Delta_{3} x_{i t(p)}^{H}$ & -1.75 & $-25.66^{* *}$ & $-38.03^{* * *}$ & $-48.14^{* *}$ & $-58.04^{* * *}$ \\
& $(4.97)$ & $(8.98)$ & $(11.16)$ & $(17.55)$ & $(18.93)$ \\
& & & & & \\
Macro controls & Yes & Yes & Yes & Yes & Yes \\
\hline$R^{2}$ & 0.144 & 0.323 & 0.396 & 0.423 & 0.478 \\
Cycles & 154 & 154 & 154 & 154 & 153 \\
\hline \hline
\end{tabular}

Within-estimator, standard errors clustered on countries in parentheses.

${ }^{* * *} \mathrm{p}<0.01,{ }^{* *} \mathrm{p}<0.05,{ }^{*} \mathrm{p}<0.1$. 
Table A.12: Expansion measured by 10-year change in credit/GDP

\begin{tabular}{|c|c|c|c|c|c|}
\hline & $\begin{array}{c}(1) \\
h=1\end{array}$ & $\begin{array}{c}(2) \\
h=2\end{array}$ & $\begin{array}{c}(3) \\
h=3\end{array}$ & $\begin{array}{c}(4) \\
h=4\end{array}$ & $\begin{array}{c}(5) \\
h=5\end{array}$ \\
\hline Average cycle & $\begin{array}{c}-1.44^{* * *} \\
(0.25)\end{array}$ & $\begin{array}{c}0.22 \\
(0.43)\end{array}$ & $\begin{array}{c}2.11^{* * *} \\
(0.51)\end{array}$ & $\begin{array}{c}3.86^{* * *} \\
(0.56)\end{array}$ & $\begin{array}{c}6.20^{* * *} \\
(0.96)\end{array}$ \\
\hline Business credit/GDP expansion $\Delta_{10} x_{i t(p)}^{B}$ & $\begin{array}{c}0.53 \\
(1.11)\end{array}$ & $\begin{array}{c}0.31 \\
(1.51)\end{array}$ & $\begin{array}{l}-0.67 \\
(1.89)\end{array}$ & $\begin{array}{l}-1.19 \\
(1.90)\end{array}$ & $\begin{array}{l}-1.23 \\
(2.86)\end{array}$ \\
\hline Household credit/GDP expansion $\Delta_{10} x_{i t(p)}^{H}$ & $\begin{array}{l}-3.12^{*} \\
(1.75)\end{array}$ & $\begin{array}{c}-12.20^{* * *} \\
(2.77)\end{array}$ & $\begin{array}{c}-16.56^{* * *} \\
(3.62)\end{array}$ & $\begin{array}{c}-20.23^{* * *} \\
(4.96)\end{array}$ & $\begin{array}{c}-22.48^{* * *} \\
(5.41)\end{array}$ \\
\hline Macro controls & Yes & Yes & Yes & Yes & Yes \\
\hline$R^{2}$ & 0.220 & 0.293 & 0.375 & 0.410 & 0.489 \\
\hline Cycles & 132 & 132 & 132 & 132 & 131 \\
\hline
\end{tabular}

Within-estimator, standard errors clustered on countries in parentheses.

${ }^{* * *} \mathrm{p}<0.01,{ }^{* *} \mathrm{p}<0.05,{ }^{*} \mathrm{p}<0.1$.

Table A.13: Expansion measured by real credit growth

\begin{tabular}{lccccc}
\hline \hline & $(1)$ & $(2)$ & $(3)$ & $(4)$ & $(5)$ \\
& $h=1$ & $h=2$ & $h=3$ & $h=4$ & $h=5$ \\
\hline Average cycle & -0.63 & -1.68 & 0.35 & 2.43 & $4.02^{*}$ \\
& $(0.67)$ & $(1.13)$ & $(1.80)$ & $(2.39)$ & $(2.07)$ \\
Business credit expansion $\Delta_{5} \log \left(\right.$ credit $\left._{i t(p)}^{B}\right)$ & $0.01^{* *}$ & $0.04^{* * *}$ & 0.03 & $0.05^{*}$ & $0.07^{* *}$ \\
& $(0.01)$ & $(0.01)$ & $(0.02)$ & $(0.03)$ & $(0.03)$ \\
Household credit expansion $\Delta_{5} \log \left(\right.$ credit $\left._{i t}{ }_{i t}\right)$ & $-0.04^{* *}$ & -0.01 & -0.02 & -0.05 & -0.05 \\
& $(0.02)$ & $(0.03)$ & $(0.05)$ & $(0.06)$ & $(0.06)$ \\
Macro controls & Yes & Yes & Yes & Yes & Yes \\
\hline$R^{2}$ & 0.184 & 0.288 & 0.336 & 0.363 & 0.422 \\
Cycles & 150 & 150 & 150 & 150 & 149 \\
\hline \hline
\end{tabular}

Within-estimator, standard errors clustered on countries in parentheses.

${ }^{* * *} \mathrm{p}<0.01,{ }^{* *} \mathrm{p}<0.05{ }^{*} \mathrm{p}<0.1$. 
Table A.14: Unconditional

\begin{tabular}{|c|c|c|c|c|c|}
\hline & $\begin{array}{c}(1) \\
h=1\end{array}$ & $\begin{array}{c}(2) \\
h=2\end{array}$ & $\begin{array}{c}(3) \\
h=3\end{array}$ & $\begin{array}{c}(4) \\
h=4\end{array}$ & $\begin{array}{c}(5) \\
h=5\end{array}$ \\
\hline Average cycle & $\begin{array}{l}-1.70^{* * *} \\
(0.00)\end{array}$ & $\begin{array}{l}-0.95^{* * *} \\
(0.00)\end{array}$ & $\begin{array}{l}0.77^{* * *} \\
(0.00)\end{array}$ & $\begin{array}{l}2.53^{* * *} \\
(0.00)\end{array}$ & $\begin{array}{l}4 \cdot 40^{* * *} \\
(0.00)\end{array}$ \\
\hline Business credit/GDP expansion $\Delta_{5} x_{i t(p)}^{B}$ & $\begin{array}{c}0.59 \\
(1.43)\end{array}$ & $\begin{array}{l}-1.64 \\
(1.90)\end{array}$ & $\begin{array}{c}-5.55 \\
(3.22)\end{array}$ & $\begin{array}{c}-6.05^{*} \\
(3.34)\end{array}$ & $\begin{array}{c}-6.43^{*} \\
(3.57)\end{array}$ \\
\hline Household credit/GDP expansion $\Delta_{5} x_{i t(p)}^{H}$ & $\begin{array}{c}0.36 \\
(2.76)\end{array}$ & $\begin{array}{c}-17.78^{* * *} \\
(3.73)\end{array}$ & $\begin{array}{c}-23.69^{* * *} \\
(4.66)\end{array}$ & $\begin{array}{c}-26.18^{* * *} \\
(6.99)\end{array}$ & $\begin{array}{c}-31.18^{* * *} \\
(7.90)\end{array}$ \\
\hline $\begin{array}{l}\beta_{h}^{B}=\beta_{h}^{H}(\mathrm{p} \text {-value }) \\
R^{2}\end{array}$ & $\begin{array}{l}0.947 \\
0.00\end{array}$ & $\begin{array}{l}0.001 \\
0.12\end{array}$ & $\begin{array}{l}0.012 \\
0.12\end{array}$ & $\begin{array}{l}0.018 \\
0.10\end{array}$ & $\begin{array}{l}0.008 \\
0.10\end{array}$ \\
\hline Cycles & 157 & 157 & 157 & 157 & 156 \\
\hline
\end{tabular}

Notes: Within-estimator, standard errors clustered on countries in parentheses. ${ }^{* * *} \mathrm{p}<0.01,{ }^{* *} \mathrm{p}<0.05,{ }^{*} \mathrm{p}<$ 0.1. Credit expansion denotes past 5-year change in credit/GDP ratio.

Figure A.7: Interacting expansions and levels

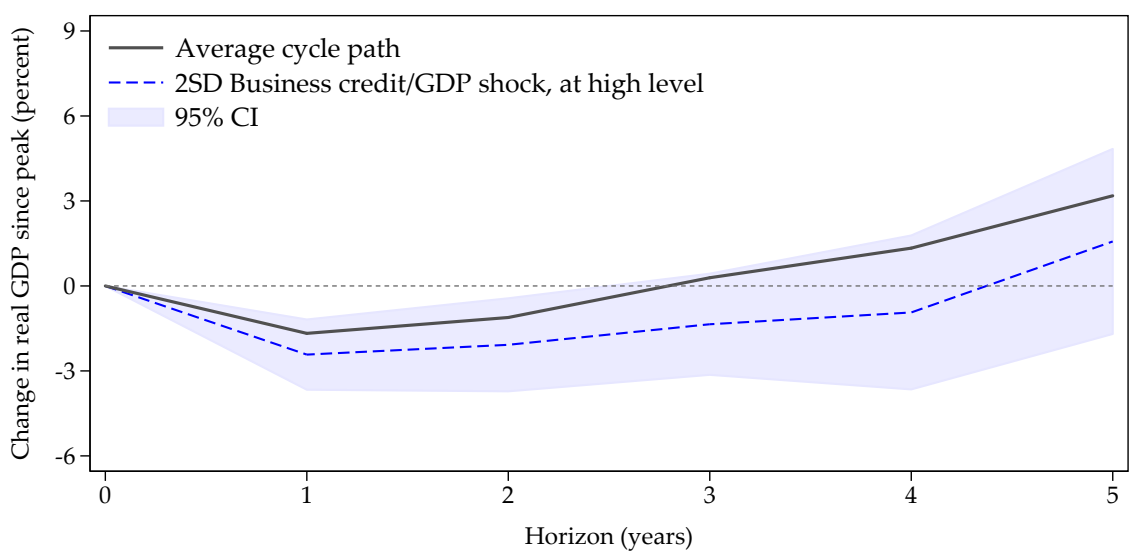

Notes: The figure visualizes the effects of business credit expansions when interacted with credit-to-GDP levels. It plots predictive effects on growth of a two-SD credit expansion in the five years preceding the recession while credit-to-GDP levels stand two standard deviations above country-specific historical averages. Estimates based on all business cycles in 17 advanced economies since 1870. Standard errors are clustered at the country level. 
Table A.15: Summary statistics for full sample of annual data

\begin{tabular}{lcccccccc}
\hline \hline & $\mathrm{N}$ & Mean & $\mathrm{SD}$ & SD resid. & Min & P10 & P90 & Max \\
\hline Business debt/GDP, 5-year change & 1286 & 0.04 & 0.16 & 0.15 & -0.63 & -0.15 & 0.22 & 0.62 \\
Household credit/GDP, 5-year change & 1218 & 0.04 & 0.08 & 0.07 & -0.35 & -0.03 & 0.13 & 0.44 \\
Business debt/GDP & 1373 & 0.86 & 0.37 & 0.19 & 0.12 & 0.44 & 1.40 & 2.14 \\
Household credit/GDP & 1313 & 0.35 & 0.26 & 0.11 & 0.00 & 0.03 & 0.72 & 1.21 \\
\hline \hline
\end{tabular}

Notes: SD resid denotes residual standard deviation after controlling for country fixed effects and countryspecific linear time trends.

\section{BUSINESS CREDIT DATA}

For parts of the post-WW2 sample, we can draw on financial accounts data of the OECD and Eurostat databases and individual publications such as Bonci and Coletta (2012) for Italy, Roe (1971) and Office for National Statistics (2016) for U.K. data, Deutsche Bundesbank (1983) and Deutsche Bundesbank (1994) for German data. All postwar U.S. data are from the Fed's Flow of Funds.

In addition, we rely on comprehensive measures of business credit provided by the "Total credit database" assembled by the Bank of International Settlements (BIS). These include secured and unsecured debt obligations of all maturities and from all types of lenders in addition to conventional bank lending contracts. For methodological details see Dembiermont, Drehmann, and Muksakunratana (2013).

For earlier years, we proxy credit growth using data on bank lending to the non-financial business sector. In addition, we extend the business lending series of Jordà, Schularick, and Taylor (2017) to obtain data for the $19^{\text {th }}$ and the first half of the $20^{\text {th }}$. We fill post-WW2 gaps with data kindly provided by Müller (2018).

For the pre-WW2 period, we calculate bank credit to the non-financial business sector based on the assets of specialized commercial banks, providing loans to business and other corporate financing. For example in the case of Germany, we sum credit extended to non-banks by joint-stock industrial banks as well as commercial credit unions. Where the banking sector is more diversified, we exploit that the bulk of pre-WW2 household loans were mortgages and obtain business credit as the residual to total private credit. Here, we can rely on Jordà, Schularick, and Taylor (2017) for necessary data on residential mortgages and total credit. We list all sources in detail below.

Table A.15 presents summary statistics of business credit and of household credit for comparison.

\section{Sources}

\section{Australia}

1948 - 1954 bank lending to non-financial corporate business from Karsten Müller (2018) Credit Markets around the World, 1910-2014. SSRN: https://ssrn. com/abstract=3259636.

1955 - 1976 residual of total bank loans to non-financial private sector and total bank loans to households (both from JST MacroHistory Database).

1977 - 1988 bank loans to business and capital market debt from "Total Credit Database" of the Bank of International Settlements: https://www.bis.org/statistics/totcredit.htm.

$1989-2013$ total non-equity liabilities of the private non-financial business sector from OECD financial accounts data. 
2014 - 2019 bank loans to business and capital market debt from "Total Credit Database" of the Bank of International Settlements: https ://www . bis.org/statistics/totcredit.htm.

\section{Belgium}

1950 - 1979 residual of total loans to non-financial private sector and total loans to households (both from JST MacroHistory Database).

1980 - 1993 bank loans to business and capital market debt from "Total Credit Database" of the Bank of International Settlements: https://www.bis.org/statistics/totcredit.htm.

$1994-2013$ OECD financial accounts data on total non-equity liabilities of the private non-financial business sector.

$2014-2019$ eurostat financial accounts data on total non-equity liabilities of the private non-financial business sector.

\section{Canada}

1884 - 1941 lending of chartered banks recorded in Urquhart, M. C., and Buckley, K. A. H., Historical Statistics of Canada, "Banking and Finance," Series H87-179 and Canada Statistical Yearbooks (various).

1942 - 1960 lending to non-financial corporate business from Karsten Müller (2018) Credit Markets around the World, 1910-2014. SSRN: https://ssrn.com/abstract=3259636.

1961 - 1969 from Statistics Canada, Table 378-0059 (terminated 2011) "Chartered banks and quasi-Banks: Loans". (accessible online at http://www5.statcan.gc.ca/cansim/ pick \0T1\textendashchoisir?lang=eng\&p2=33\&id=3780059).

$1970-2013$ OECD financial accounts data on total non-equity liabilities of the private non-financial business sector.

2014 - 2019 bank loans to business and capital market debt from "Total Credit Database" of the Bank of International Settlements: https ://www.bis.org/statistics/totcredit.htm.

\section{Denmark}

1875 - 1950 Business loans of banks proxied by lending and domestic bills of exchange from commercial banks from Johannsen (1985).

1951 - 1993 from Abildgren (2007), ibid. Appendix B, Table B.1 and B.2, Series "Commercial lending".

$1994-2013$ OECD financial accounts data on total non-equity liabilities of the private non-financial business sector.

$2014-2018$ eurostat financial accounts data on total non-equity liabilities of the private non-financial business sector.

2019 bank loans to business and capital market debt from "Total Credit Database" of the Bank of International Settlements: https://www.bis.org/statistics/totcredit.htm. 


\section{Finland}

1948 - 1969 calculated from Statistics Finland (various), Statistical Yearbook (various issues). Table "Loans by the credit institutions by groups of borrowers on 31 December", Series "Total w/o municipalities and parishes". Base is 1970 value.

1970 - 1994 bank loans to business and capital market debt from "Total Credit Database" of the Bank of International Settlements: https://www.bis.org/statistics/totcredit.htm.

1995 - 2013 financial accounts data on total non-equity liabilities of the private non-financial business sector.

2014 - 2019 eurostat financial accounts data on total non-equity liabilities of the private non-financial business sector.

\section{France}

1902 - 1933 residual of total bank credit from JST database (from Saint Marc, Patat and Lutfalla) less real estate lending from Crédit Foncier.

1958 - 1976 from Annual Reports of the Conseil National du Crédit, published between 1959 and 1976: Crédit aux entreprises industrielles et comercielles, total series. Available at www.gallica.bnf.fr.

1977 - 1994 bank loans to business and capital market debt from "Total Credit Database" of the Bank of International Settlements: https://www.bis.org/statistics/totcredit.htm.

1995 - 2012 OECD financial accounts data on total non-equity liabilities of the private non-financial business sector.

$2013-2018$ eurostat financial accounts data on total non-equity liabilities of the private non-financial business sector.

2019 bank loans to business and capital market debt from "Total Credit Database" of the Bank of International Settlements: https://www.bis.org/statistics/totcredit.htm.

\section{Germany}

1885 - 1920 from Bundesbank (1976): loans and discounts of joint-stock banks (Aktienkreditbanken) and commercial credit unions (Genossenschaftsbanken) to non-banks proxying lending to business.

1924 - 1944 from Bundesbank (1976): loans and discounts of Großbanken and Kreditgenossenschaften.

1949 - 1990 from Deutsche Bundesbank (1983) "Revidierte Ergebnisse der gesamtwirtschaftlichen Finanzierungs- und Geldvermögensrechnung für die Jahre 1950-1959", and Deutsche Bundesbank (1994) "Ergebnisse der gesamtwirtschaftlichen Finanzierungsrechnung für Westdeutschland 1960-1992. Total private non-financial business sector liabilities less equity.

1991 - 2012 OECD financial accounts data on total non-equity liabilities of the private non-financial business sector. 
$2013-2018$ eurostat financial accounts data on total non-equity liabilities of the private non-financial business sector.

2019 bank loans to business and capital market debt from "Total Credit Database" of the Bank of International Settlements: https://www.bis.org/statistics/totcredit.htm.

\section{Ireland}

1932 - 2002 from Rebecca Stuart (2017) "70 years of personal disposable income and consumption in Ireland", Journal of the Statistical and Social Inquiry Society of Ireland, Vol.46, pp.47-70 and sourced cited therein: Bank lending to business.

2003 - 2018 from Central Bank of Ireland's online Bank Balance Sheets Data, Table A.5 "Loans to the Irish Private Sector", credit to the private non-financial business sector.

\section{Italy}

1948 - 1949 bank lending to non-financial corporate business from Karsten Müller (2018) Credit Markets around the World, 1910-2014. SSRN: https://ssrn. com/abstract=3259636.

1950 - 1994 financial accounts data on total non-equity liabilities from Bonci and Coletta (2012) "Italy's Financial Accounts since 1950", SSRN: http://ssrn. com/abstract=2120474.

1995 - 2012 OECD financial accounts data on total non-equity liabilities of the private non-financial business sector.

$2013-2018$ eurostat financial accounts data on total non-equity liabilities of the private non-financial business sector.

2019 bank loans to business and capital market debt from "Total Credit Database" of the Bank of International Settlements: https://www.bis.org/statistics/totcredit.htm.

\section{Japan}

1948 - 1963 from Nihon Ginkō Tōkeikyoku and Nihon Ginkō Chōsakyoku (various) as well as Honpō-Keizai-Tōkei and Nihon Ginkō Toōkeikyoku, Tokyo. 1948-59: Table "All banks: Loans classified by industry", Series "Total without lending to private households, local governments, and financial institutions". 1960-61: Table "Outstanding loans and discounts of all banks by industry", Series "Total (without lending to private persons, local governments, and finance)". 1962-63: Table "All banks (banking accounts): Loans classified by industry", Series "Total without loans to households, local government, financials, and companies overseas" + Table "All banks (trust accounts): Loans classified by industry", Series "Total without loans to households, local government, financials, and companies overseas".

1964 - 1979 bank loans to business and capital market debt from "Total Credit Database" of the Bank of International Settlements: https ://www.bis.org/statistics/totcredit.htm.

1980 - 2012 OECD financial accounts data on total non-equity liabilities of the private non-financial business sector.

2013 - 2019 bank loans to business and capital market debt from "Total Credit Database" of the Bank of International Settlements: https://www.bis.org/statistics/totcredit.htm. 


\section{Netherlands}

1946 - 1989 bank lending to business sector proxied by loans of "Handelsbanken" from De Nederlandsche Bank (2000).

1990 - 1994 bank loans to business and capital market debt from "Total Credit Database" of the Bank of International Settlements: https://www.bis.org/statistics/totcredit.htm.

$1995-2018$ eurostat financial accounts data on total non-equity liabilities of the private non-financial business sector.

2019 bank loans to business and capital market debt from "Total Credit Database" of the Bank of International Settlements: https://www.bis.org/statistics/totcredit.htm.

\section{Norway}

1872 - 1939 bank lending to non-financial business sector proxied by commercial bank lending from Historical Monetary Statistics for Norway.

1940 - 1974 bank lending to non-financial corporate business from Karsten Müller (2018) Credit Markets around the World, 1910-2014. SSRN: https://ssrn.com/abstract=3259636.

1975 - 1994 bank loans to business and capital market debt from "Total Credit Database" of the Bank of International Settlements: https://www.bis.org/statistics/totcredit.htm.

$1995-2013$ OECD financial accounts data on total non-equity liabilities of the private non-financial business sector.

2014 - 2019 eurostat financial accounts data on total non-equity liabilities of the private non-financial business sector.

\section{Portugal}

1947 - 1978 bank lending to non-financial corporate business from Karsten Müller (2018) Credit Markets around the World, 1910-2014. SSRN: https://ssrn. com/abstract=3259636.

1979 - 1994 bank loans to business and capital market debt from "Total Credit Database" of the Bank of International Settlements: https://www.bis.org/statistics/totcredit.htm.

$1995-2013$ OECD financial accounts data on total non-equity liabilities of the private non-financial business sector.

$2014-2019$ eurostat financial accounts data on total non-equity liabilities of the private non-financial business sector.

\section{Spain}

1904 - 1935 bank lending to business from Estadisticas Historicas de Espana, by Lopez, Carreras, and Tafunell (1989); table 9.12: Entitades de credito.

1946 - 1979 residual of total bank loans to non-financial private sector and total loans to households (both from JST MacroHistory Database). 
1980 - 2012 OECD financial accounts data on total non-equity liabilities of the private non-financial business sector.

2013 - 2019 eurostat financial accounts data on total non-equity liabilities of the private non-financial business sector.

\section{Sweden}

$1872-1940$ residual of total bank loans to non-financial private sector and total loans to households (both from JST MacroHistory Database); total bank loans less loans of housing credit institutions.

1975 - 1979 bank loans to business calculated from Statistics Sweden (various), Financial Market Statistics. Series: "Housing credit institutions' lending, SEK millions", Series "Nonfinancial corporations" + Series: "Banks' total landing and lending to non-MFI, SEK million", Series "Non-financial corporations - Total", Series "Financial corporate sector, not MFI - Total".

1980 - 1994 bank loans to business and capital market debt from "Total Credit Database" of the Bank of International Settlements: https://www.bis.org/statistics/totcredit.htm.

$1995-2013$ OECD financial accounts data on total non-equity liabilities of the private non-financial business sector.

2014 - 2019 eurostat financial accounts data on total non-equity liabilities of the private non-financial business sector.

\section{Switzerland}

1870 - 1976 bank loans to business from JST MacroHistory Database, building on Swiss National Bank. "Historical Time Series." 2009. Section 5: "Banks in Switzerland".

1977 - 1998 bank loans to business from Swiss National Bank, "Historical Time Series 5." 2009. "Banks in Switzerland.", Table 21 "Sectoral breakdown of domestic assets", Series "Non-Financial Corporations, Private legal entities".

$1999-2011$ OECD financial accounts data on total non-equity liabilities of the private non-financial business sector.

2012 - 2019 bank loans to business and capital market debt from "Total Credit Database" of the Bank of International Settlements: https://www.bis.org/statistics/totcredit.htm.

\section{United Kingdom}

1880 - 1950 residual of total bank loans to non-financial private sector and total loans to households from JST MacroHistory Database.

1951 - 1956 Bank of England (2017); Table LPQBC57 (accessible online at http: //www . bankofengland . co.uk/).

1957 - 1966 total non-equity liabilities of the private non-financial business sector from Roe (1971) "The financial interdependence of the UK economy 1957-66", London: Chapman and Hall. 
1967 - 1986 total non-equity liabilities of the private non-financial business sector from the Office of National Statistics (2016), "Pre-ESA95 financial accounts and balance sheets", (accessible online at https://www.ons.gov.uk/economy/nationalaccounts/uksectoraccounts).

$1987-2013$ OECD financial accounts data on total non-equity liabilities of the private non-financial business sector.

2014 - 2019 bank loans to business and capital market debt from "Total Credit Database" of the Bank of International Settlements: https://www.bis.org/statistics/totcredit.htm.

\section{United States of America}

1916 - 1938 total corporate debt less interbank debt from James, John A. and Richard Sylla (2006), "Debt and Flow of Funds" in "Historical Statistics of the United States" edited by Susan B. Carter and Scott Sigmund Gartner and Michael R. Haines and Alan L. Olmstead and Richard Sutch and Gavin Wright.

1945 - 2019 total loans, bonds and miscellaneous liabilities of non-financial corporate businesses and total loans and miscellaneous liabilities of non-financial non-corporate businesses from Board of Governors of the Federal Reserve System (2020) "Financial Accounts of the United States". 